\title{
Simultaneous Cross-Linking and Cross-Polymerization of Enzyme Responsive Polyethylene Glycol Nanogels in Confined Aqueous Droplets for Reduction of Low- Density Lipoprotein Oxidation
}

Basak, Suman; Khare, Harshvardhan Ajay; Roursgaard, Martin; Kempen, Paul ; Lee, Jong Hyun; BazbanShotorbani, Salime; Kræmer, Martin; Chernyy, Sergey; Andresen, Thomas Lars; Almdal, Kristoffer Total number of authors:

11

Published in:

Biomacromolecules

Link to article, DOI:

10.1021/acs.biomac.0c01238

Publication date:

2021

Document Version

Peer reviewed version

Link back to DTU Orbit

Citation (APA):

Basak, S., Khare, H. A., Roursgaard, M., Kempen, P., Lee, J. H., Bazban-Shotorbani, S., Kræmer, M., Chernyy, S., Andresen, T. L., Almdal, K., \& Kamaly, N. (2021). Simultaneous Cross-Linking and Cross-Polymerization of Enzyme Responsive Polyethylene Glycol Nanogels in Confined Aqueous Droplets for Reduction of Low-Density Lipoprotein Oxidation. Biomacromolecules, 22(2), 386-398. https://doi.org/10.1021/acs.biomac.0c01238

\section{General rights}

Copyright and moral rights for the publications made accessible in the public portal are retained by the authors and/or other copyright owners and it is a condition of accessing publications that users recognise and abide by the legal requirements associated with these rights.

- Users may download and print one copy of any publication from the public portal for the purpose of private study or research.

- You may not further distribute the material or use it for any profit-making activity or commercial gain

- You may freely distribute the URL identifying the publication in the public portal 


\section{Simultaneous cross-linking and cross-polymerization of enzyme responsive polyethylene glycol nanogels in confined aqueous droplets for reduction of low-density lipoprotein oxidation}

Suman Basak ${ }^{l}$, Harshvardhan Ajay Khare ${ }^{1,2}$, Martin Roursgaard ${ }^{3}$, Paul J. Kempen ${ }^{l}$, Jong Hyun Lee ${ }^{l}$, Salime Bazban-Shotorbani ${ }^{1}$, Martin Kramer ${ }^{l}$, Sergey Chernyy ${ }^{l}$, Thomas L. Andresen ${ }^{l}$, Kristoffer Almdal ${ }^{4}$, Nazila Kamaly ${ }^{1,5 *}$

${ }^{1}$ Department of Health Technology, DTU Health Tech, Technical University of Denmark, 2800, Kgs. Lyngby, Denmark

${ }^{2}$ Department of Clinical Physiology, Nuclear Medicine \& PET and Cluster for Molecular Imaging, Rigshospitalet and University of Copenhagen, 2200, Copenhagen, Denmark

${ }^{3}$ Department of Public Health, Section of Environmental Health, University of Copenhagen, 1014, Copenhagen K, Denmark

${ }^{4}$ Department of Chemistry, Technical University of Denmark, 2800, Kgs. Lyngby, Denmark

${ }^{5}$ Department of Chemistry, Molecular Sciences Research Hub, Imperial College London, London, W12 0BZ, UK

Email: Nazila.kamaly@imperial.ac.uk 


\begin{abstract}
A key initiating step in atherosclerosis is the accumulation and retention of apolipoprotein B complexing lipoproteins within artery walls. In this work, we address this exact initiating mechanism of atherosclerosis, which results from the oxidation of low-density lipoproteins (oxLDL) using therapeutic nanogels. We present the development of biocompatible polyethylene glycol (PEG) crosslinked nanogels formed from a single simultaneous cross-linking and copolymerization step in water without the requirement for organic solvent, high temperature or shear stress. The nanogel synthesis also incorporates in situ non-covalent electrostatically driven template polymerization around an innate anti-inflammatory and anti-oxidizing paraoxonase-1 (PON-1) enzyme payload - the release of which is triggered due to matrix metalloproteinase (MMP) responsive elements instilled in the PEG crosslinker monomer. Results obtained demonstrate the potential of triggered release of PON-1 enzyme and its efficacy against the production of ox-LDL and therefore a reduction in macrophage foam cell and reactive oxygen species formation.
\end{abstract}

\title{
KEYWORDS
}

Nanogels, Nanomedicine, Paraoxonase-1, Atherosclerosis, Low-density lipoprotein, Matrix metalloproteinases 


\section{INTRODUCTION}

Cholesterol is transported in plasma by apolipoprotein particles. When these cholesterolapolipoprotein particles such as low-density lipoproteins (LDL) accumulate in the subendothelium of large or medium-sized arteries in regions of disturbed blood flow where the endothelial barriers are compromised - they are retained and become oxidised, leading to an accumulation of oxidised LDL (oxLDL) within the subendothelium. ${ }^{1-3}$ These species generate an inflammatory response that leads to an influx of monocyte-derived macrophages. ${ }^{4}$ Macrophages ingest the oxLDL and become lipid laden 'foam cells' that eventually die, leading to the deposition of cellular debris and cholesterol crystals that form a necrotic core..$^{5}$ In addition, these activated macrophages release pro-inflammatory cytokines that signal the recruitment of further monocytes, $\mathrm{T}$ cells and neutrophils into the plaque. ${ }^{6}$ Subsequently, inflammation is initiated by innate immune reactions and perpetuated by $\mathrm{T}$ cells that react to autoantigens from oxLDL (in particular to the B100 protein in LDL). ${ }^{4}$ This self-perpetuating oxidation and aggregation of LDL continues to promote foam cell formation and a pro-inflammatory response. Eventually, the atherosclerotic plaque grows in size and becomes unstable leading to rupture or endothelial erosion, which can lead to thrombus formation causing vessel occlusion and myocardial infarction or ischaemic stroke. OxLDL in fact has many roles in promoting atherogenesis. ${ }^{5}$ To date, human trials involving dietary antioxidants that act on oxLDL have failed to show improvements. ${ }^{5}$ Therapies that can interfere with the oxidation and retention of LDL are therefore of paramount importance in our fight against atherosclerosis.

One group of potential therapeutics that are proving to be potent contenders as novel therapies are biologics. ${ }^{7}$ Biologics such as siRNA, mRNA and DNA biomolecules, proteins including enzymes, antibodies and regulatory proteins are becoming preferred therapeutics of choice due to numerous 
advantages over small molecule drugs. ${ }^{8}$ For example, enzymes offer exquisite specificity and can work at catalytic outputs. As production, scale-up and testing of biological drugs progresses, the translation and commercialization of these specific and potent therapies will rise. However, biological drugs can suffer from poor bioavailability, short half-lives in vivo, protease damage, short shelf-life, costly production and immunogenic side-effects. ${ }^{9}$ The current standard for addressing some of these limitations is that of covalent PEGylation of the protein surface, which can prolong the proteins half-life and biocompatibility in vivo, however, since this is a covalent approach it can also lead to loss of protein activity. ${ }^{10}$ The encapsulation of therapeutic proteins within biocompatible polymeric nanoparticles presents a more amenable approach, whereby the proteins do not need to be surface modified chemically, and can be protected until the site-of action. ${ }^{11,12}$ For example, in our previous work we have shown that the delivery of innate biological molecules such as interleukin-10 or a peptide pharmacophore of annexin A1 protein (Ac2-26) can successfully resolve inflammation in advanced atherosclerotic plaques, leading to a reduction in both lesional oxidative stress and necrosis, and increasing collagen content and fibrous cap thickness in mice, when delivered using controlled-release polymeric nanoparticles. ${ }^{20,21,13}$

In the innate setting, the oxidation of LDL can be prevented by protective enzymes such as glutathione peroxidase, ${ }^{14}$ lipoprotein-PLA2, ${ }^{15}$ and paraoxonases. ${ }^{16}$ Although key enzymes in atherosclerosis such as hydroxy-methyl-glutaryl CoA (HMG-CoA) reductase, ${ }^{17}$ and protein convertase subtilisin/kexin type 9 inhibitors $(\mathrm{PCSK} 9)^{18}$ have been exploited as pharmacological targets, the delivery of anti-atherogenic enzymes represents a relatively unexplored area. As such in this study we chose to investigate the anti-oxidizing effects of paraoxonase-1 (PON-1) retained within nanogel nanoparticles with matrix metalloproteinase responsive elements for its triggered release. Paraoxonases (PONs) are antioxidant enzymes that have the ability to protect against the 
oxidation of LDL leading to a reduction of peroxide and aldehyde by-products, and are associated with high density lipoproteins (HDL) in serum. ${ }^{19}$ PONs have three isotypes: PON-1, PON-2 and PON-3. PON-1 and PON-3 are associated with HDL in plasma and PON-2 is an intracellular enzyme. ${ }^{20} \mathrm{PON}-1$ is the most studied of the three forms and has been shown to not only prevent the accumulation of oxidized LDL, but to also promote cholesterol efflux from macrophages. ${ }^{5}$ Since both HDL-associated PON and purified PON were shown to be potent inhibitors of LDL oxidation, PON delivery is therefore a viable therapeutic approach, and the presence of PON in HDL can therefore be a major contributor to HDL's potent anti-atherogenic capability. ${ }^{19,} 21$ Furthermore, purified PON-1 treatment of oxLDL was observed to significantly decrease the ability of oxLDL to induce endothelial cell activation and monocyte binding. ${ }^{16}$ Several studies to date have confirmed the protective role of PON-1, for example, deletion of the PON-1 gene was shown to increase atherosclerosis in mice, ${ }^{22}$ and overexpression of PON-1 led to a reduction in atherosclerosis in both normal and Apoe ${ }^{-/}$mice in a dose-dependent manner. ${ }^{23}$ In human studies, polymorphisms in PON-1 lead to an increase in the risk of atherosclerosis. ${ }^{21}$ Replenishing and delivering PON-1 to atherosclerotic plaques within protective nanogels is therefore an attractive therapeutic option. Therefore, local nanogel delivery of PON-1 in a controlled release manner due to specific and 'triggered' release can lead to a sustained level of bioactive PON-1 enzyme.

Nanogels are hydrogels within the nanometer range consisting of crosslinked porous polymer networks with the ability to retain high volumes of water or biological fluids whilst maintaining their structure. ${ }^{24-26}$ They have a wide range of flexibility in their design, allowing their characteristics such as size, charge, degree of porosity and degradability to be easily tuned by the choice of monomeric building blocks. ${ }^{27}$ Since nanogels can retain a high volume of water, they are extremely biocompatible. This excellent and unique property makes them an ideal 
nanoplatform for the delivery of biological drugs such as enzymes and proteins. ${ }^{28,29}$ Nanogels are prepared via polymerization of monomers or precursors by chemical crosslinking or via physical crosslinking of preformed polymers via amphiphilic or electrostatic interactions. ${ }^{30}$ Nanogels have superior properties as they offer: 1) encapsulation stability for biologically sensitive payloads, 2) they have low immunogenicity and toxicity, and can be designed to be fully biodegradable, 3) multiple biological payloads can be delivered in a single nanogel, facilitating combination therapies, 4) their synthesis can be aqueous based and easily scaled, and 5) they are soft nanoparticles that can easily squeeze through restricted sites under hemodynamic shear flow. In this manner, nanogels are the ideal delivery platform for biological drugs especially since biological therapeutics can be encapsulated into nanogels using mild aqueous reaction conditions. By incorporating labile bonds within precursor monomers, nanogels can be designed to be responsive to a wide variety of environmental stimuli such as enzymes, temperature, $\mathrm{pH}$ and ionic strength. ${ }^{31-33}$ These functionalities can be easily achieved with the right monomer design. This strategy of triggered disintegration makes crosslinked polymeric nanogels a promising system for the controlled delivery of biologics. In this work, we exploited the up-regulation of matrix metalloproteinases in atherosclerosis as a method to trigger the release of PON-1 from the nanogels and bestow a more 'controlled' release of this potent enzyme. ${ }^{34,35}$ The PON-1 enzyme can be protected and encapsulated in situ during the nanogel formation process, this ensures high encapsulation efficiencies and a good degree of dispersion of the protein throughout the nanogel network. Furthermore, how tightly the proteins are held within the nanogels can be tuned by the degree of crosslinking. ${ }^{36,37}$ In this work, we have developed MMP-2 responsive nanogels composed of mainly a crosslinked PEG network with an acrylamide co-polymerized backbone. The PON-1 enzyme was templated with a charged quaternary amine monomer which was then 
blended into the one-pot aqueous polymerization reaction (Figure 1). This green methodology did not require the use of solvents, high temperature or shear stress, and led to homogenous sub 100 nm nanogels with a viable payload of PON-1 enzyme. Biological investigations confirmed PON1 activity and efficacy in activated macrophages using three bioassays for oxLDL, foam cell and reactive oxygen species (ROS) production assessment in vitro. This proof-of-concept study is a first demonstration of the therapeutic potential of PON-1 nanotherapy in an atherosclerotic setting.

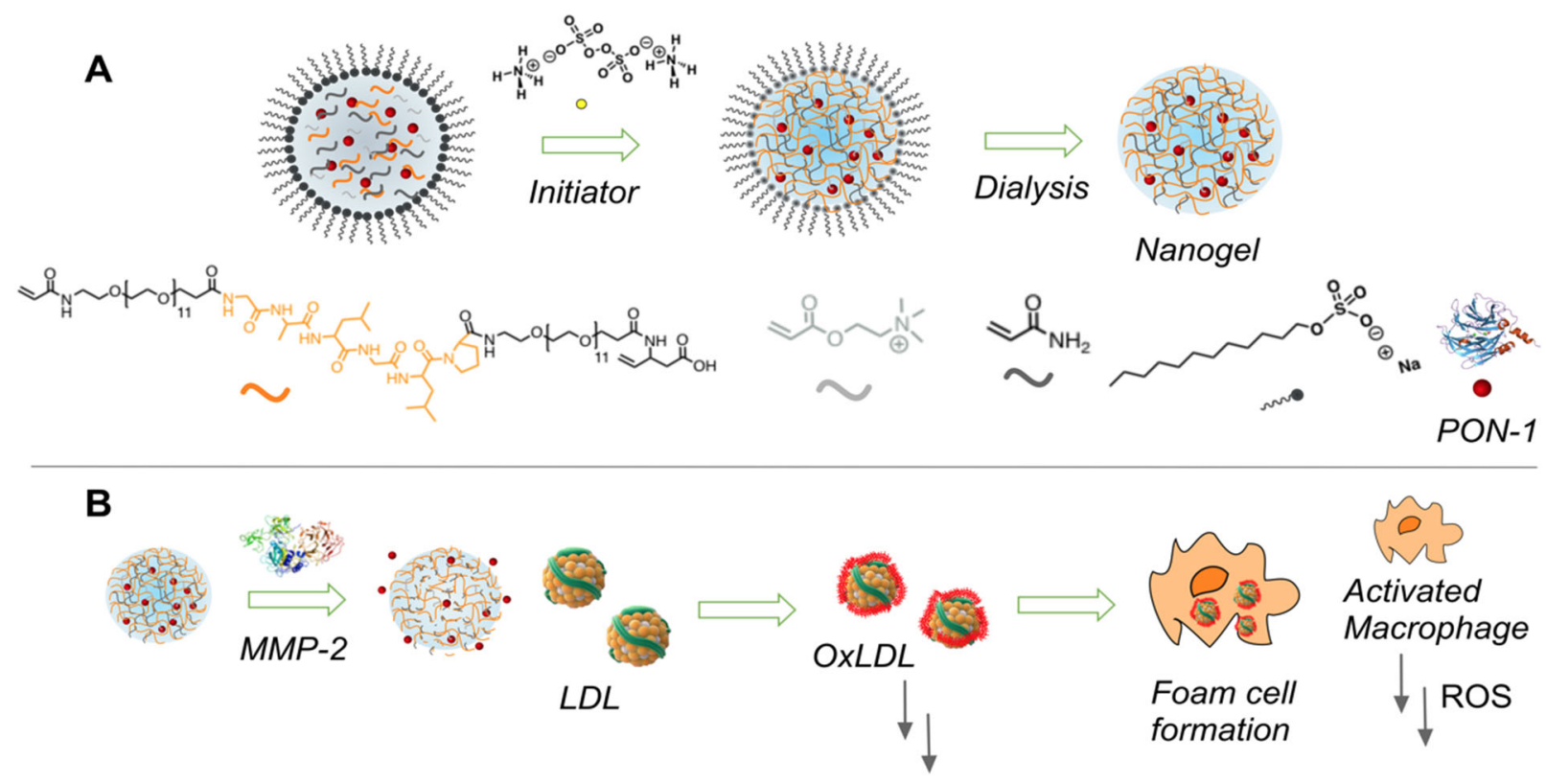

Figure 1. Overall nanogel design and application to the reduction of oxLDL species, macrophage foam cell and ROS production. (A) The required monomer units are encapsulated within micellar cores formed as a result of sodium dodecyl sulfate surfactant use at above critical micelle concentrations in water. Simultaneous crosslinking (due to the MMP cleavable crosslinker) and co-polymerization (due to acrylamide) in one-pot in total aqueous conditions was initiated using ammonium persulfate to form nanogels that entrap PON-1. PON-1 was previously electrostatically templated with charged polymerizable trimethylammonium chloride salt, which allowed for co-polymerization of this protein bound monomer into the nanogels. The nanogels 
were then purified via dialysis and tested for their MMP-2 responsiveness. (B) The nanogels were further incubated with LDL particles, and their effects on reducing and blocking their oxidation, in addition to macrophage foam cell formation and ROS generation was assessed in vitro.

\section{EXPERIMENTAL METHODS}

Materials. All materials and reagents were used as purchased without further purification. FmocN-amido-dPEG ${ }^{\circledR 12-a c i d ~ w a s ~ p u r c h a s e d ~ f r o m ~ Q u a n t a ~ B i o D e s i g n ~ L t d, ~ U S A . ~ F m o c-(S)-3-A m i n o-~}$ 5-hexenoic acid was purchased from abcr GmbH, DE. 2-Chlorotrityl chloride, all L-amino acids: Fmoc-Gly-OH, Fmoc-Ala-OH, Fmoc-Leu-OH and Fmoc-Pro-OH, 1[Bis(dimethylamino)methylene]-1H-1,2,3-triazolo[4,5-b]pyridinium3-oxid hexafluorophosphate

(HATU), N,N-diisopropylethylamine (DIPEA), acryloyl chloride, [2(acryloyloxy)ethyl]trimethylammonium chloride (AETC) solution (80 wt. \% in H2O), acrylamide (AM), ammonium persulfate (APS), $\mathrm{N}, \mathrm{N}, \mathrm{N}^{\prime}, \mathrm{N}^{\prime}$-tetramethylethylenediamine (TEMED), cell culture grade bovine serum albumin (BSA), human LDL, MDA lipid peroxidation assay kit, Oil Red O solution ( $0.5 \%$ in isopropanol), cell counting Kit -8 (CCK8), Dulbecco's Phosphate Buffered Saline (PBS), Dulbecco's Modified Eagle's medium (DMEM), MMP-2 (human, recombinant, expressed in E.coli), calcium chloride $(\mathrm{CaCl} 2)$ chloroform-d $(\mathrm{CDCl} 3)$, deuterium oxide (D2O), dichloromethane (DCM), anhydrous N,N-Dimethylformamide (DMF), trifluoroacetic acid (TFA), sodium dodecyl sulfate (SDS), 2,4,6-collidine, 2,5-dihydroxybenzoic acid, sodium trifluoroacetate, 2,4,6-trimethylpyridine, anhydrous methanol (MeOH) and piperidine were all purchased from Sigma-Aldrich, DK. Paraoxonase-1 (human, recombinant, expressed in E. coli) was purchased from BioVendor, UK. PON-1 activity assay kit was from 
BioVision Inc, USA. PON-1 ELISA kit came from antibodies-online GmbH, DE. Hoechst 33342 Solution $(20 \mathrm{mM})$ and ProLong ${ }^{\circledR}$ Gold mount media, and Micro BCA ${ }^{\mathrm{TM}}$ Protein Assay Kit were from Thermo Fisher Scientific ${ }^{\mathrm{TM}}$, DK. Acryloxyethyl thiocarbamoyl Rhodamine B (RMA) was purchased from Polysciences Europe GmbH, DE.

Instrumentation. Solid phase synthesis was carried out using a Biotage ${ }^{\circ}$ Initiator + Alstra ${ }^{\mathrm{TM}}$ automated microwave peptide synthesizer (Biotage, SE). Thin layer chromatography (TLC) was used to monitor reactions and products where appropriate, using $254 \mathrm{~nm} \mathrm{UV}$ light or $\mathrm{KMnO}_{4}$ visualization. Analytical reversed-phase high-performance liquid chromatography (RP- HPLC) was performed on a Shimadzu instrument (equipped with a LC-20AD pump, a DGU-20A SR degassing unit, and a SPD-M20A Photodiode Array (PDA) Detector) with an Eclipse Plus C18, 4.6 × $250 \mathrm{~mm}, 5 \mu \mathrm{m}$ column. HPLC Eluent A was: a 5\% $\mathrm{CH}_{3} \mathrm{CN}$ aqueous solution with $0.1 \%$ trifluoroacetic acid (TFA); HPLC Eluent B was: $0.1 \%$ TFA in $\mathrm{CH}_{3} \mathrm{CN} .{ }^{1} \mathrm{H}$ NMR was recorded at $400 \mathrm{MHz}$. Chemical shifts $(\delta)$ are reported in parts per million (ppm) relative to the solvent's signal peak. Mass spectra were recorded on a Bruker Reflex IV MALDI-TOF Spectrometer. Dynamic light scattering (DLS) and $\zeta$ - potential measurements were performed on a Malvern Zetasizer Nano-ZS instrument. UV-vis spectroscopy was carried out by using the Beer-Lambert law using a Thermo scientific nanodrop 2000-C instrument. The path length of $1 \mathrm{~cm}$ UV cuvette was filled up with a $1 \mathrm{~mL}$ sample solution and the UV scan carried out at room temperature. Spark® multimode microplate reader Tecan was used to carry out the absorbance and fluorescence measurements. Confocal Microscopy studies used an upright laser scanning microscope Zeiss LSM 710 with $63 \times$ magnification and the fluorescence nanogels intensity was collected at $\lambda$ ex: $553 \mathrm{~nm}$. 
Synthesis and characterization of MMP cleavable crosslinker 9. The acryloylamino-dPEG12GALGLP-dPEG12-amido-hexenoic acid crosslinker was synthesized by solid-phase synthesis (SPPS) using a 2-chlorotritylchloride polymer bound resin (100 mg, $0.10 \mathrm{mmol}, 1$ eq., 100-200 mesh, 1.0 mmol g-1 loading) via standard Fmoc SPPS methodology. The resin was first added to a $10 \mathrm{~mL}$ SPPS glass reaction vessel and washed with DCM $(5 \times 5 \mathrm{~mL})$ and allowed to swell in $\operatorname{DCM}(5 \mathrm{~mL})$ for $30 \mathrm{~min}$. The (S)-3-(Fmoc-amino)-5-hexenoic acid (175 mg, $0.5 \mathrm{mmol}, 5 \mathrm{eq}$.) and DIEA ( $174 \mu \mathrm{l}, 1.0 \mathrm{mmol}, 10 \mathrm{eq}$.) were added ato the vessel nd the reaction shaken for $24 \mathrm{~h}$ at room temperature. After $24 \mathrm{~h}$ the reaction was stopped and unreacted residue washed with DCM $(3 \times 5$ $\mathrm{mL})$ and DMF $(3 \times 5 \mathrm{~mL})$. The resin was dried and photometric analysis was used to calculate the loading efficiency of the resin after the initial conjugation step and was found to be $0.60 \mathrm{mmol} \mathrm{g}$ 1 loading. Any remaining reactive sites on the resin were then capped using a DCM:MeOH:DIPEA: 17:2:1 v/v mixture and the resin shaken for $30 \mathrm{~min}$. The resin was then washed with DMF (3 x $5 \mathrm{~mL}), \mathrm{DCM}(3 \times 5 \mathrm{~mL}), \mathrm{MeOH}(3 \times 5 \mathrm{~mL})$ and finally with DMF $(3 \times 5$ $\mathrm{mL}$ ) and dried to yield 1 . After this initial resin coupling step, the remaining synthetic steps were performed on an automated peptide synthesizer (Biotage initiator+ alstra) with microwave technology at $75{ }^{\circ} \mathrm{C}$. The Fmoc group was removed using 20\% piperidine in DMF for 13 min to yield 2. The first Fmoc-N-amido-dPEG®12-acid (4.08 eq.) residue was coupled with the (S)-3(Fmoc-amino)-5-hexenoic ester resin using HATU (4.0 eq.), and 2,4,6-collidine (8.0 eq.) in DMF for $5 \mathrm{~min}$ at $75^{\circ} \mathrm{C}$ to yield 3 . The Fmoc group was removed using 20\% piperidine in DMF for 13 min to give 4, and then each amino acid coupling was carried out using Fmoc protected amino acid (4.08 eq.), HATU (4.0 eq.), and 2,4,6-collidine (8 eq.) in DMF for $5 \mathrm{~min}$ at $75{ }^{\circ} \mathrm{C}$ thereafter and deprotected in a similar manner using 20\% piperidine in DMF for 13 min after each amino acid 
coupling. Completion of each coupling and deprotection step was monitored by the Kaiser test. Next the second Fmoc-N-amido-dPEG ${ }^{\circledR} 12$-acid (4.08 eq.) molecule was coupled with 5 using using HATU (4.08 eq.), and 2,4,6-collidine ( 8.0 eq.) in DMF for 5 min at $75^{\circ} \mathrm{C}$ to yield 6 . The Fmoc group was removed using $20 \%$ piperidine in DMF for 13 min to give 7 which was washed with DMF (5 x $5 \mathrm{~mL})$ and dried. Dry DCM (3 mL) was added to 7, and the acrylation step was carried out using manual SPPS, where acryloyl chloride ( $24.24 \mu \mathrm{L}, 0.30 \mathrm{mmol}, 5$ eq.) and DIPEA $(174 \mu \mathrm{L}, 10$ eq.) were dissolved in dry DCM $(3 \mathrm{~mL})$ and added to 7 , and the reaction shaken for 4 $\mathrm{h}$ at room temperature. The resin was then washed with DMF $(5 \times 5 \mathrm{~mL}), \mathrm{DCM}(5 \times 5 \mathrm{~mL}), \mathrm{MeOH}$ ( $5 \times 5 \mathrm{~mL}), \mathrm{DMF}(5 \times 5 \mathrm{~mL})$ and dried to give 8 . Finally, the crosslinker was cleaved from the resin using TFA:DCM 1:1 v/v $(10 \mathrm{~mL})$ in a $50 \mathrm{~mL}$ round bottomed flask. The resin was then filtered and washed with DCM $(2 \times 10 \mathrm{~mL})$ and the solvent removed in vacuo to yield a yellow compound which was further purified using flash coloumn chromatrography using DCM:MeOH 9:1 as the eluent $\mathrm{v} / \mathrm{v}$. The solvent was removed in vacuo and the product lyophilized from $\mathrm{H}_{2} \mathrm{O}$ to give a yellow powder $9(15.8 \mathrm{mg}, 14 \%$, purity $>97 \%)$. $1 \mathrm{H} \mathrm{NMR} \mathrm{(400} \mathrm{MHz,} \mathrm{D2O):} \delta 6.33-6.18(\mathrm{~m}$, 1H), 5.86-5.75 (m, 1H), 5.58-5.50 (m, 1H), 5.20-5.04 (m, 2H), 4.69-4.62 (m, 1H), 4.56-4.23 (m, $6 \mathrm{H}), 4.17-3.15(\mathrm{~m}, 145 \mathrm{H}), 2.81-1.07(\mathrm{~m}, 41 \mathrm{H}), 0.99-0.86(\mathrm{~m}, 12 \mathrm{H})$. HPLC: product eluted at 8.9 min as a sharp peak. Eluent: (A) $5 \% \mathrm{CH}_{3} \mathrm{CN}+0.1 \%$ TFA in $\mathrm{H}_{2} \mathrm{O}$, (B) $0.1 \%$ TFA in $\mathrm{CH}_{3} \mathrm{CN}$. Gradient profile: Linear gradient from $0 \%$ B to $100 \%$ B over $20 \mathrm{~min}$. Flow rate: $0.5 \mathrm{~mL} / \mathrm{min}$. Solvent for injection: H2O/acetic acid (4:1). MALDI-TOF MS (m/z): Calc. mass $[\mathrm{M}+\mathrm{H}]+$ : 1890.09, found mass $[\mathrm{M}+\mathrm{Na}]+:$ 1912.88. MALDI-TOF spectrum of the product was obtained using 2,5-Dihydroxybenzoic acid $(60 \mathrm{mg} / \mathrm{mL})$ with TFA $(2 \mathrm{mg} / \mathrm{mL})$ in $\mathrm{MeOH}$ as matrix. 


\section{Proteolysis of acryloylamino-dPEG12-GALGLP-dPEG12-amido-hexenoic acid crosslinker}

9 with MMP-2 enzyme. The crosslinker 9 was incubated with MMP-2 enzyme for 24 h at $37^{\circ} \mathrm{C}$ in buffer (50 mM HEPES, $10 \mathrm{mM} \mathrm{CaCl} 2,150 \mathrm{mM} \mathrm{NaCl}, 20 \%$ glycerol, $0.005 \%$ BRIJ®-35 Detergent, $\mathrm{pH}$ 7.5). For this experiment the crosslinker was used at $1 \mathrm{mM}$ and the MMP-2 enzyme at $50 \mathrm{nM}$ concentrations. At the end of the incubation period, the enzyme was removed using ultracentrifugation Amicon filters (100 KDa MWCO), desalted and the final cleaved products assessed using MALDI-TOF. MALDI-TOF MS (m/z): Calc. mass for positive fragment [M+H]+: 995, found mass [M+Na]+: 1018 MALDI-TOF spectrum of the product was obtained using 2,5Dihydroxybenzoic acid $(60 \mathrm{mg} / \mathrm{mL})$ with TFA $(2 \mathrm{mg} / \mathrm{mL})$ in $\mathrm{MeOH}$ as matrix.

Nanogel synthesis and characterization. In a typical run, BSA (2 mg, $15 \mu \mathrm{M})$ or PON-1 (250 $\mu \mathrm{g}, 2.9 \mu \mathrm{M})$ were dissolved in $1 \mathrm{~mL}$ of milli-Q water and mixed with AETC (12 mg, $30 \mathrm{mM})$. The mixture was stirred for 10 min to allow electrostatic binding of a positively charged monomer to a negatively charged protein surface. Then, acrylamide $(10 \mathrm{mg}, 70 \mathrm{mM})$, peptide based crosslinker (9 mg, $7 \mathrm{mM}$ ) each dissolved in $1 \mathrm{~mL}$ of milli-Q water were added and the mixture was deoxygenated by bubbling with $\mathrm{N} 2$ for $10 \mathrm{~min}$. Afterwards, SDS ( $2 \mathrm{mg}, 7 \mathrm{mM})$ dissolved in $1 \mathrm{~mL}$ of deoxygenated milli-Q water was added and the mixture stirred for $30 \mathrm{~min}$ to allow micelle formation. In the last step, APS (1 mg, $2 \mathrm{mM})$ dissolved in $1 \mathrm{~mL}$ of milli-Q water was added followed by TEMED $(20 \mu \mathrm{L}, 134 \mu \mathrm{mol})$. The mixture stirred for $4 \mathrm{~h}$ at r.t. and later dialyzed (100 kDa MWCO, Spectra/Por ${ }^{\circledR}$ ) against milli-Q water with at least three water changes over a period of $48 \mathrm{~h}$. The nanogels were stored at $4{ }^{\circ} \mathrm{C}$ or lyophilized for long term storage. 
Nanogel size and charge storage stability. The storage stability of the protein loaded nanogels was carried out by storing the samples at $4{ }^{\circ} \mathrm{C}$ for 1 month and measuring their size and zeta potential in PBS and DI water at $25^{\circ} \mathrm{C}$, and $37^{\circ} \mathrm{C}$. Dynamic light scattering (DLS) was used to analyze the size and the charge of the nanogels using Malvern zetasizer Nano-ZS with backscatter detection at $173^{\circ}$. Three scans were performed each time and each run measured 15 number of sub-scanning cycles $(n=3)$. Size and zeta measurement were carried out at $25^{\circ} \mathrm{C}$ and $37^{\circ} \mathrm{C}$ in Deionized water (DI water) and PBS.

Transmission electron microscopy (TEM). Samples were prepared by adding $10 \mu \mathrm{L}$ of nanogel $(1 \mathrm{mg} / \mathrm{mL}$ ) on to a glow discharged formvar coated 200 mesh, copper grid (Electron Microscopy Sciences, FCF200-Cu) and allowing to adsorb for 3 minutes before removing the excess sample by blotting gently with filter paper. The grids were then rinsed on 3 droplets of DI water in quick succession and stained with a droplet of $1 \%$ uranyl acetate in water for 30 seconds. The excess stain was removed by blotting with filter paper and the grids were allowed to dry at room temperature before TEM imaging. TEM images were acquired using an FEI Tecnai T20 at the Center for Electron Nanoscopy at Denmarks Technical University.

Micro-BCA assay for protein quantification in nanogels. To quantify the amount of protein inside the nanogels we carried out a standard micro-BCA assay ${ }^{38} \mathrm{~A}$ standard curve with a defined concentration of protein solution was generated according to the micro-BCA assay. The protein loaded nanogel was centrifuged using Amicon filters with $100 \mathrm{KDa}$ MWCO for BSA and $50 \mathrm{KDa}$ MWCO for PON-1 nanogels at 2000 rpm for 10 minutes and the filtrate was collected and its absorbance at $562 \mathrm{~nm}$ measured. The absorbance value corresponds to the exact free protein 
concentration and the bound protein could therefore be calculated. To determine the loading efficiency (LE \%) and encapsulation efficiency (EE \%) we have used the following calculation:

$$
\begin{aligned}
& \% \mathrm{EE}=\frac{\text { amount of measured protein mass }}{\text { amount of protein mass added }} \times 100 \\
& \% \mathrm{LE}=\frac{\text { amount of measured protein mass }}{\text { Total empty nanogel mass }} \times 100
\end{aligned}
$$

Cumulative protein release from nanogels post incubation with MMP-2 enzyme. BSA or PON-1 protein loaded nanogels (4.76 mg contains $200 \mu \mathrm{g}$ BSA or $2.5 \mu \mathrm{g}$ NG- 1_PON1 contains $100 \mathrm{ng}$ PON1) were incubated with $50 \mathrm{nM}$ MMP-2 enzyme in $500 \mu \mathrm{L}$ Tris buffer at $37^{\circ} \mathrm{C}$ and at either 2,4, $6 \mathrm{~h}$ of incubation the reaction was quenched with $20 \mathrm{mM}$ EDTA and the solution centrifuged using Amicon filters (100 KDa MWCO) at $5000 \mathrm{rpm}$ for 10 minutes. The protein amount in the filtrates was quantified using the micro-BCA assay. For PON-1 nanogels, PON-1 release was measured using an ELISA kit.

Released PON-1 activity measurement. Released PON-1 activity was measured using a commercially available activity assay kit (BioVision). The native PON-1 protein (100 ng) and the PON-1 protein loaded nanogels with equivalent PON-1 dose were incubated with $50 \mathrm{nM}$ MMP-2 enzyme in $500 \mu \mathrm{L}$ Tris buffer at $37^{\circ} \mathrm{C}$ and at $48 \mathrm{~h}$ interval the filtrate was collected (by $50 \mathrm{KDa}$ amicon filter, $5000 \mathrm{rpm}$ for $15 \mathrm{~min}$ ) and the released proteon activity. The BioVision's PON1 activity assay kit enables the measurement of PON-1 activity by utilizing a fluorogenic substrate, which measures a highly fluorescent product $(\mathrm{Ex} / \mathrm{Em}=368 / 460 \mathrm{~nm})$ and this can be used as a measure of enzymatic activity. 
In vitro cell viability. RAW 264.7 cells were seeded in a 96 well plate $\left(5 \times 10^{3}\right.$ cells per well) in $200 \mu \mathrm{L}$ of DMEM buffer with 10\% FBS and 1\% penicillin and allowed to grow for $24 \mathrm{~h}$ under incubation at $37{ }^{\circ} \mathrm{C}$ and $5 \% \mathrm{CO}$. Then different concentration of nanogels (NG-1) (such as: 0 $\mu \mathrm{g} / \mathrm{mL}, 10 \mu \mathrm{g} / \mathrm{mL}, 50 \mu \mathrm{g} / \mathrm{mL}, 100 \mu \mathrm{g} / \mathrm{mL}, 250 \mu \mathrm{g} / \mathrm{mL}, 500 \mu \mathrm{g} / \mathrm{mL}$ ) were investigated for $24 \mathrm{~h}$ and $48 \mathrm{~h}$ and the viability measured using the Cell Counting Kit-8 (CC-K8) assay (Sigma-Aldrich).

Cellular uptake assay. The cellular uptake of fluorescence labeled nanogels was investigated using RAW 264.7 cells, which were seeded into 12 well plates $\left(1 \times 10^{5}\right.$ cells per well $)$ in $1 \mathrm{~mL}$ of DMEM buffer with $10 \%$ FBS and 1\% penicillin and incubated for $24 \mathrm{~h}$ prior to the experiment. Then the cells were incubated with LPS $100 \mathrm{ng} / \mathrm{mL}$ and $100 \mathrm{IU} / \mathrm{mL}$ IFN- $\gamma$ (for treated cells) or, without (for untreated cells) for $24 \mathrm{~h}$ and then fluorescently labeled NG-1_PON-1_RMA $(0.1 \%$ of RMA, $100 \mu \mathrm{g} / \mathrm{mL}$ ) was added to the cells and incubated for a further $24 \mathrm{~h}$. The medium was removed and the cells washed with PBS (3 x $1 \mathrm{~mL})$. The nuclei were stained with 4',6-diamidino2-phenylindole (DAPI) and the cells were imaged after $24 \mathrm{~h}$ using confocal laser scanning microscopy with an excitation at $\lambda$ ex: $553 \mathrm{~nm}$.

Oil red O assay. Oil red O (ORO) assay was carried out to determine whether treatment of PON1 enzyme is effective in inhibiting foam cell formation. Briefly, RAW264.7 cells were stimulated with LPS $(100 \mathrm{ng} / \mathrm{mL})$ and $100 \mathrm{IU} / \mathrm{mL}$ IFN- $\gamma$ for $24 \mathrm{~h}$ then treated with $50 \mu \mathrm{g} / \mathrm{mL}$ of ox-LDL for 24 h. Cells were preincubated with $10 \mu \mathrm{g} / \mathrm{ml}$ PON-1 or PON-1 loaded nanogels. Control experiment was done without the addition of ox-LDL $(50 \mu \mathrm{g} / \mathrm{mL})$ to cells. Washed the cells with DMEM buffer and cell fixation was done by adding $10 \%$ formalin solution for 15 minutes, 
followed by staining with a $1 \mathrm{~mL}$ of ORO and hematoxylin cocktail mixture. An optical microscope was used to observe the stained cells. For quantification of the oil droplet formation, PBS buffer in each well was carefully discarded and the wells air dried for 10 minutes. Then, the stained cells in each well were soaked in 2-propanol for 15 minutes to extract the dye. The lysis solution was transferred to a microplate to measure the absorbance at $492 \mathrm{~nm}$ using a plate reader. The level of oil droplet formation was expressed as a value relative to that in the control group.

LDL oxidation. Human plasma LDL was commercially purchased (Sigma-Aldrich) and dialyzed in deionized water for $24 \mathrm{~h}$ at room temperature (50 KDa MWCO Spectra/Por $\left.{ }^{\circledR}\right)$ to remove ethylenediaminetetraacetate (EDTA), and was subsequently either oxidized alone or in the presence of PON-1 enzyme. LDL was oxidized with $5 \mu \mathrm{M} \mathrm{Cu}^{2+}$ for $4 \mathrm{~h}$ at $37{ }^{\circ} \mathrm{C}$ and dialysis was then repeated to remove the $\mathrm{Cu}^{2+}$.

Thiobarbituric acid reactive substance (TBARS) assay. The TBARS assay was performed according to the Lipid Peroxidation (MDA) Assay Kit (Sigma-Aldrich). Briefly, copper oxidized LDL was reconstituted in $20 \mu \mathrm{L}$ PBS buffer and mixed with $500 \mu \mathrm{L}$ of $42 \mathrm{mM}$ sulfuric acid in a $1.5 \mathrm{~mL}$ Eppendorf tube. Then, $125 \mu \mathrm{L}$ of phosphotungstinic acid was added and the and the Eppendorf vortexed for 2 minutes. The sample was incubated at room temperature for 5 minutes and centrifuged at 13,000 g for 3 minutes. The top layer was collected and mixed with $2 \mu \mathrm{L}$ of BHT in $100 \mu \mathrm{L}$ of deionized water and the final volume was adjusted to $200 \mu \mathrm{L}$. Finally, $600 \mu \mathrm{l}$ of TBA solution was mixed together with the $200 \mu \mathrm{L}$ analyte solution and incubated at $95^{\circ} \mathrm{C}$ for 60 minutes and the UV absorbance of the solution measured at $532 \mathrm{~nm}$. 
Reactive oxygen species (ROS) assay. THP-1 monocytes were obtained from the American Type Culture Collection (Manassas, VA, USA) and cultured in RPMI-1640 medium supplemented with $1 \%$ HEPES, $1 \%$ sodium pyruvate, $0.1 \%$ gentamicin, and $10 \%$ fetal bovine serum. The THP- 1 cells were differentiated into adherent macrophages (denoted THP-1 activated) by treatment with $10 \mathrm{ng} / \mathrm{mL}$ phorbol 12-myristate 13-acetate (PMA, Sigma, St. Louis, MO, USA) overnight. The THP-1 activated cells attach to the surface of the culture flasks, whereas THP-1 cells stay in suspension and were removed with the supernatant. After differentiation, $5 \times 10^{5}$ cells per well were seeded in $200 \mu \mathrm{L}$ in a black 96 well plate, and left for re-attachment for 24 hours. The cells were then exposed to different concentrations of the PON-1 $(0.4 ; 2.0 ; 4.0$ and $8.0 \mu \mathrm{g} / \mathrm{mL})$, empty nanogels (NG: $10 ; 50 ; 100$ and $200 \mu \mathrm{g} / \mathrm{mL})$ or PON-1 loaded nanogels PON-1/NG (0.4/10; 2/50; $4 / 100$ and $8 / 200 \mu \mathrm{g} / \mathrm{mL}$ ) for 24 hours. After the exposure the cells were washed once with Hanks buffer $(200 \mu \mathrm{L}$ ) and then incubated with $10 \mu \mathrm{M}$ DCFH probe (Sigma, D6883-50MG) in $100 \mu \mathrm{L}$ for 15 minutes at $37^{\circ} \mathrm{C}$. The extracellular DCFH was washed away with Hanks buffer $(3 \times 200$ $\mu \mathrm{L}$ ), and $1 \mathrm{mM} \mathrm{H} 2 \mathrm{O} 2$ in $200 \mu \mathrm{L}$ was added for 2 hours to induce ROS production, and the level of ROS production was measured by the amount of fluorescence signal in each well determined at $(\lambda \mathrm{ex}=485 \mathrm{~nm} ; \lambda \mathrm{em}=538 \mathrm{~nm})$ usa a fluorescence spectrophotometer (Fluoroskan Ascent FL; Labsystems). The results were normalized to the non-treated control and represent the average of three independent experiments.

\section{Results and Discussion}

Synthesis and characterization of MMP cleavable cross-linker, 9. In order to create nanogels that will release their PON-1 payload specifically within plaque environments we chose to instill 
a cleavable sequence within a PEG crosslinker monomer that was responsive to MMP activity. The entrapment of labile enzymes within crosslinked PEG networks is an effective way to recover enzyme activity and provides a mild encapsulating condition - given the delicate nature of this type of protein. Up to now, a wide range of MMP responsive nanoparticles have been developed, making this approach a reliable and proven methodology for the triggered release of drugs in an in vivo setting. ${ }^{39-41}$ In atherosclerosis, activated macrophages secret high levels of MMPs and several have been identified as having disease progression roles such as matrix degradation and plaque destabilization, and include MMP-1, MMP-2, MMP-3, MMP-8 and MMP-9. ${ }^{34}$ In particular, MMP-2 and MMP-9 levels were shown to be far greater in atherosclerosis pathology. ${ }^{34}$ Therefore, we chose to utilize MMP-2 activity and we selected the -GAL $\downarrow$ GLP- cleavable sequence by these MMPs according to previously published studies. ${ }^{42,43}$ In the first instance the acryloylamino-dPEG 12 -GALGLP-dPEG12-amido-hexenoic acid crosslinker 9 with the MMP-2 cleavable motif was synthesized using Fmoc solid phase peptide synthesis (SPPS) as shown in Scheme 1. The first step in the SPPS involved the loading of 2-chlorotritylchloride resin with $(S)$ 3-(Fmoc-amino)-5-hexenoic acid to give the Fmoc protected resin bound product 1. Subsequently Fmoc-based SPPS using an automated peptide microwave synthesizer was used to synthesize cross-linker 9 starting with Fmoc deprotection using 20\% piperidine in DMF to give 2. Next the first Fmoc- $N$-amido-dPEG ${ }^{\circledR}$ 12-acid molecule was coupled using HATU/2,4,6-collidine in DMF to give 3 , followed by deprotection with $20 \%$ piperidine in DMF to yield 4 . The sequential coupling of the required L-amino acids was then carried out using Fmoc SPPS in the same manner to give 5, which was coupled with the second Fmoc- $N$-amido-dPEG ${ }_{12}$-acid molecule to give 6. Following Fmoc removal (7), acrylation was carried out with acryloyl chloride and DIPEA in DCM to give 8. Post washing steps with aprotic and protic solvents, the crosslinker was cleaved 
from resin using TFA/DCM 1:1 v/v and washed in cold diethyl ether and dried. The final product was taken up in DCM and purified using flash column chromatography yielding the highly watersoluble yellow hygroscopic compound $\mathbf{9}$, and characterized by ${ }^{1} \mathrm{H}$ NMR (SI Figure 1), analytical HPLC corresponding to $>97 \%$ purity (SI Figure 2a) and MALDI-TOF with $\mathrm{m} / \mathrm{z}=1912.88$ corresponding to $[\mathrm{M}+\mathrm{Na}]+$ (SI Figure 2b). For the synthesis of the cross-linker discrete PEG (dPEG) units were utilized in order to produce as homogenous a monomer and therefore nanogel as possible. ${ }^{44}$ Additionally, each PEG molecule spacer length flanking the peptide sequence was approximately $46 \AA$ in order to create smaller aqueous pore sizes so as to minimize unwanted diffusion of PON-1 protein molecules out of the nanogels in the absence of MMP activity. Although in this instance the nanogels are passively targeted, a free carboxylic acid was retained on product 9 in order to allow for future bioconjugations of targeting moieties to the surface of the nanogels and to provide further solubility. 


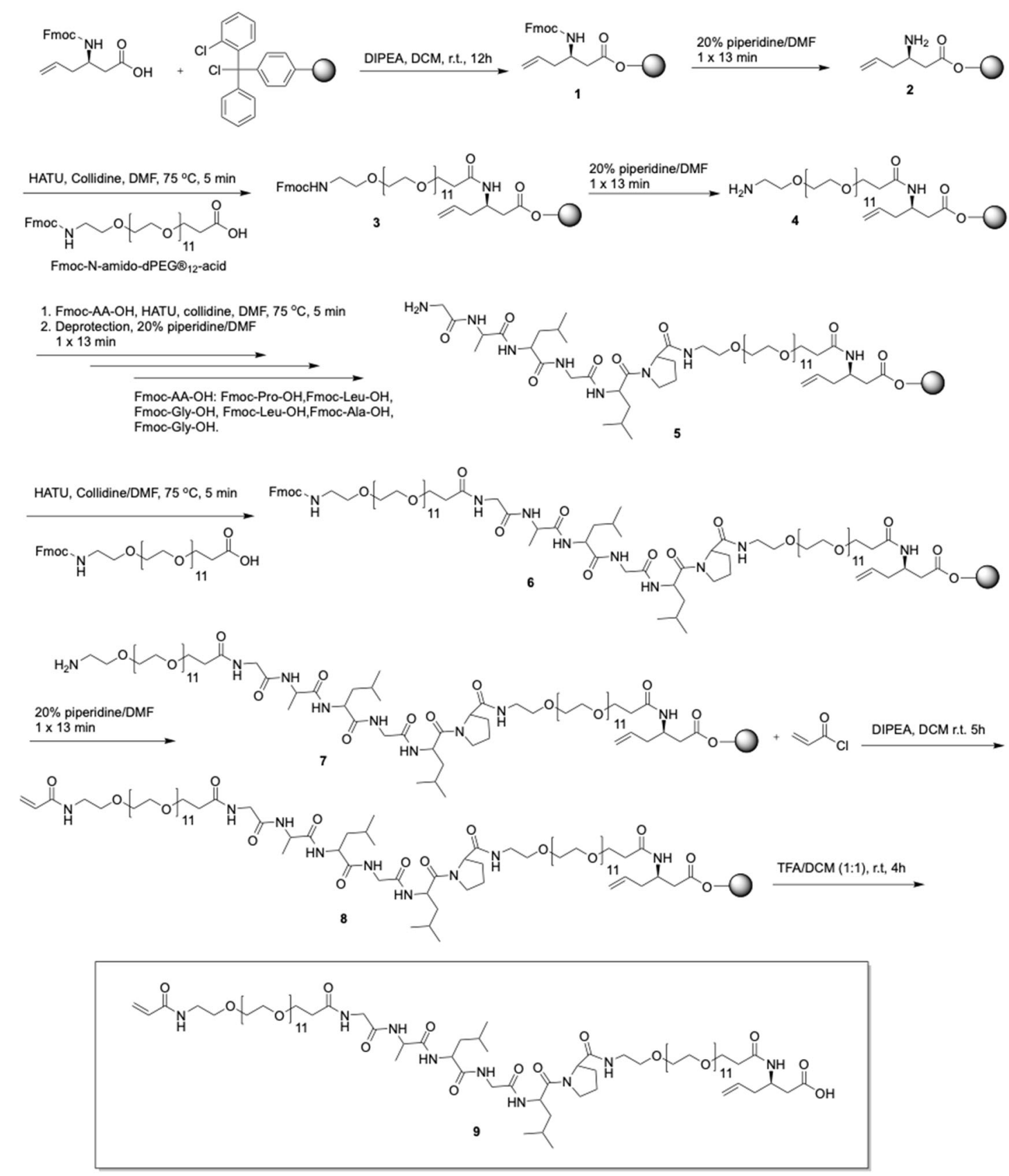

Scheme 1. Fmoc solid phase peptide synthesis of acryloylamino-dPEG $12-$ GALGLP-dPEG $_{12-}$ amido-hexenoic acid cross-linker 9.

Proteolysis of acryloylamino-dPEG 12 -GALGLP-dPEG 12 -amido-hexenoic acid crosslinker 9 with MMP-2 enzyme. We next verified the cleavability of the acryloylamino-dPEG ${ }_{12}-$ GAL $\downarrow$ GLP-dPEG 12 -amido-hexenoic acid crosslinker 9 by incubation with MMP-2 enzyme for 24 
$\mathrm{h}$ at $37^{\circ} \mathrm{C}$ in buffer $\left(50 \mathrm{mM}\right.$ HEPES, $10 \mathrm{mM} \mathrm{CaCl}_{2}, 150 \mathrm{mM} \mathrm{NaCl}, 20 \%$ glycerol, $0.005 \%$ BRIJ®35 Detergent, $\mathrm{pH}$ 7.5). For this experiment the crosslinker was used at $1 \mathrm{mM}$ and the MMP-2 enzyme at $50 \mathrm{nM}$ concentrations. At the end of the incubation period enzyme was removed using ultracentrifugation and the final cleaved products assessed using MALDI-TOF. Two fragments corresponding to cleavage between the $\mathrm{L}+\mathrm{G}$ amino acid sequences were proposed (SI Figure 3A) and we were able to identify the positive cleavage fragment with $\mathrm{m} / \mathrm{z} 1018\left([\mathrm{M}+\mathrm{Na}]_{+}(\mathbf{S I}\right.$ Figure 3B) with MALDI-TOF. With confirmation that the crosslinker is responsive to MMP-2 activity, we then proceeded to nanogel synthesis.

Nanogel synthesis and characterization. To effectively deliver PON-1 enzyme embedded into nanogels, the reaction conditions should be mild without the need for high shear stress, elevated temperatures or organic solvents. As such we utilized an aqueous polymerization method, with no organic solvent, need for heating or ultrasonication. The nanogels were synthesized by mixing all the required constituent monomers including; the acryloylamino-dPEG12-GALGLP-dPEG12amido-hexenoic acid cross-linker 9, [2-(Acryloyloxy)ethyl]trimethylammonium (AETC) salt, acrylamide (AM), (SDS) surfactant, and polymerization was initiated using $N, N, N^{\prime}, N^{\prime}-$ tetramethylethylenediamine (TEMED) base and ammonium persulfate (APS) initiator (Figure 2). Prior to this step, the PON-1 enzyme was allowed to mix with the AETC monomer for 30 min at room temperature, ${ }^{45}$ the remaining components were added to the reaction vessel and stirred for a further 30 minutes at room temperature in order to allow for micelle formation (SI Figure 4). Finally, the TEMED and APS were added in a dropwise manner and the nanogels were allowed to form over a period of 4 hours in total aqueous conditions. The nanogels were then purified using dialysis in $\mathrm{dH}_{2} \mathrm{O}$ for 24 hours. The methodology we employed for nanogel synthesis involved 
dispersing the monomers in water, with the addition of the classical emulsifier SDS, which led to the monomers accumulating within the micellar core. The addition of APS and TEMED leads to initiator radicals generated in the aqueous phase, which then migrate into the micelles that are swollen with the monomer molecules and polymerization occurs. This methodology led to both crosslinking and co-polymerization of the backbone in a single step. Crosslinked nanogels are often synthesized using heterogeneous polymerization employing solvents, however we have shown that the use of organic solvents and high temperatures are not necessary in this case. Prior to using PON-1 enzyme, the conditions for nanogel synthesis were optimized using BSA as a model protein and 5 nanogels with varying amounts of constituents were investigated (SI Table 1).

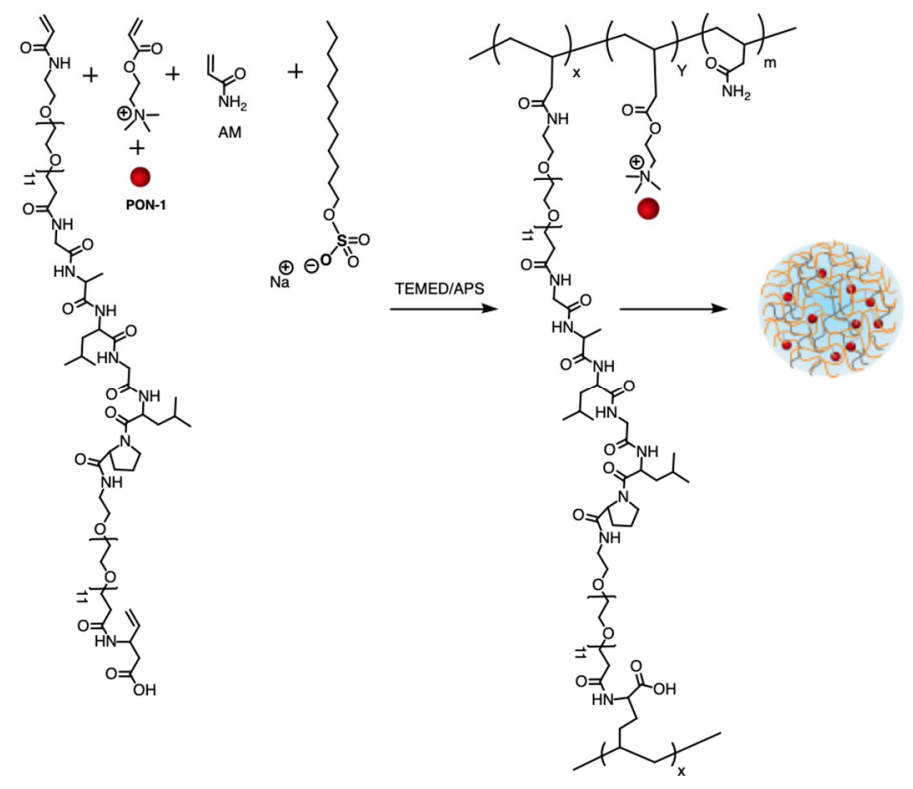

Figure 2. Nanogel synthesis. Polymeric nanogels were synthesized using TEMED and APS initiator in deionized water. 
The concentration of the cationic AETC and AM were varied and the remaining constituents were kept constant and the nanogels synthesized according the above described methodology. The hydrodynamic diameter of the NG-1_BSA to NG-5_BSA nanogels were measured to be within the $60 \pm 1.0$ to $141.0 \pm 2.0 \mathrm{~nm}$ range using DLS (SI Table 2 and SI Figure 5). The zeta potential of the 5 BSA-nanogels were measured to be $-16.0 \pm 2.0$ to $-31.0 \pm 0.5 \mathrm{mV}$ with polydispersity indexes ranging between $0.27 \pm 0.01$ to $0.44 \pm 0.05$ (SI Table 2). Furthermore, minimal changes were observed in the hydrodynamic diameter and zeta potential for all 5 nanogels when incubated at 25 or $37^{\circ} \mathrm{C}$ indicating stable formulations (SI Figure 6). These results confirm that the nanogels formed by covalent bonds via crosslinking are colloidally stable under physiological temperature and do not dissociate, with minimal changes in their size and surface properties (i.e charge). From these results it was determined that nanogel-1 (NG1_BSA) polymerization was the most optimal condition since it led to small size nanoparticles, with the lowest PDI and a zeta potential closest to neutral (SI Table 2). Therefore, this condition was selected for PON-1 encapsulation.

Although we utilized BSA protein for optimizing the nanogel synthesis conditions, when PON-1 was used in the same formulations, little difference was observed in the size of the nanogels made using either protein (Figure 3). Although BSA and PON-1 have different isoelectric points and macromolecular structure, we wanted to demonstrate the suitability of our nanogel design for the encapsulation of a standard protein such as BSA in addition to a therapeutic protein. The native proteins, BSA and PON-1 were found to be 6.5 and $5.2 \mathrm{~nm}$ in PBS, empty nanogels (containing no protein), were measured to have a hydrodynamic size of $19.0 \pm 1.2 \mathrm{~nm}$ (Figure 3B and 3D). Upon protein encapsulation the size of the BSA and PON-1 nanogels increased to 69 and $58 \mathrm{~nm}$, respectively. TEM analysis also confirmed the small size and spherical morphology of the developed nanogels and little difference was observed between the BSA vs PON-1 nanogel shape 
and morphology, though PON-1 nanogels were found to be slightly smaller in size (Figure 3A and C).
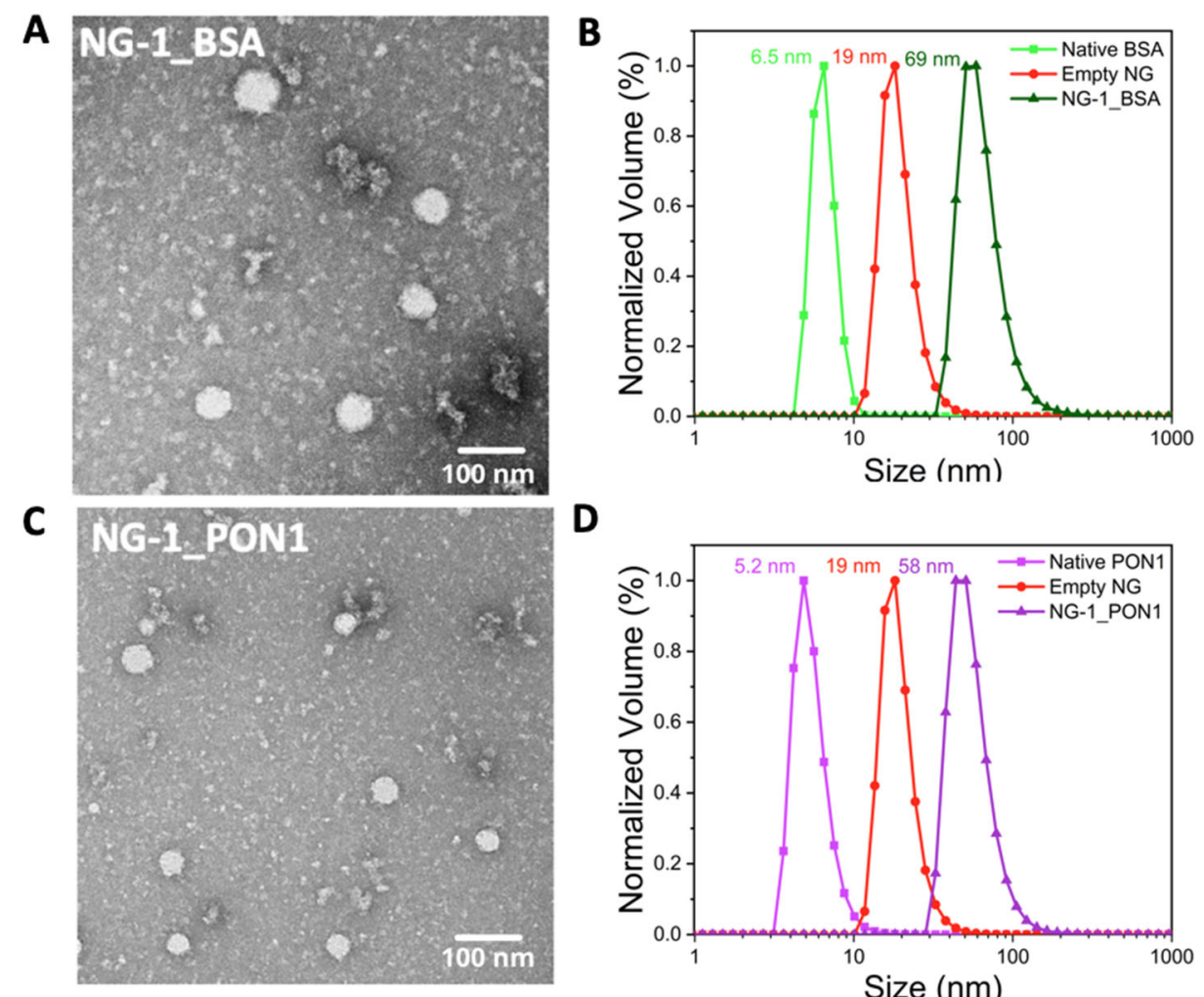

D

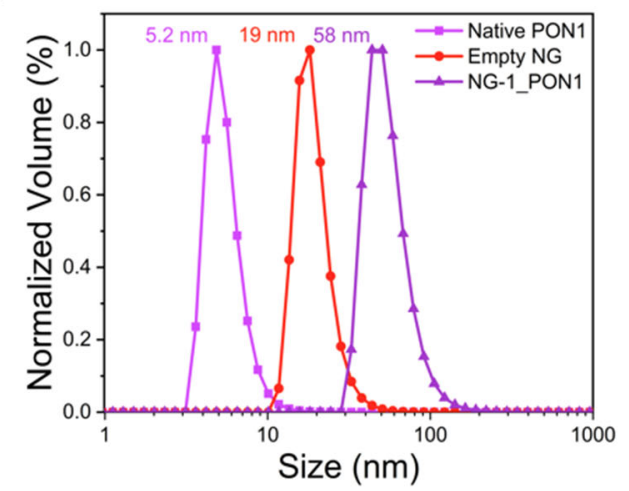

Figure 3. Comparison of PON-1 and BSA nanogel size by TEM and DLS. (A) Negative stain TEM of NG-1_BSA nanogels, (B) normalized volume DLS of NG-1_BSA and controls, (C) negative stain TEM of NG-1_PON-1 nanogels, (D) normalized volume DLS of NG-1_PON-1 and controls.

The hydrodynamic size and surface charge stability (and therefore aggregation potential) of the optimized NG-1_BSA nanogel was measured by investigating both DLS and zeta potential measurements at two temperatures of $25{ }^{\circ} \mathrm{C}$ and $37{ }^{\circ} \mathrm{C}$ in both PBS and deionized water for up to 30 days (SI Figure 7). Remarkably we found little change in the nanogel overall size and charge 
in either water or PBS up to 30 days at both temperatures and this confirms the high stability of these covalently crosslinked nanogels. In further assessing the stability of the PON-1 enzyme pre and post encapsulation within the nanogels, we measured the activity of the un-encapsulated and encapsulated PON-1 enzyme using a fluorometric activity assay and found their activities to be comparable (SI Figure 8).

In order to track the nanogels in cellular studies, the optimized condition of NG_1 polymerization was further investigated with the inclusion of varying concentrations of rhodamine $b$ methacrylate (RMA) in the polymerization mixture to yield 3 fluorescent nanogels with either $0.1,0.5$ or $1 \%$ RMA molar concentrations (SI Table 3). In the first instance the polymerization of RMA into NG1_BSA_RMA was confirmed with an observable strong peak in the UV-vis spectrum of these nanogels at $552 \mathrm{~nm}$ corresponding to RMA, which was absent in the control non-fluorescent NG1-BSA (Figure 4A). Measurement of the hydrodynamic size of these nanogels in solution revealed an increase in hydrodynamic size from approximately $73.0 \pm 2.0$ to $145 \pm 5.0 \mathrm{~nm}$ for the NG1_BSA nanogels and $58.7 \pm 3.2$ to $61.47 \pm 1.7 \mathrm{~nm}$ for the NG-1_PON-1 nanogels as the concentration of RMA was increased (SI Table 4). The increase in size following increasing amounts of RMA grafting could be due to increased molecular crowding and therefore larger core sizes (Figure 4B). Next the cumulative release of both BSA and PON-1 protein from NG-1 nanogels was measured post incubation with MMP-2 enzyme (Figure 4C + 4D). NG-1_BSA nanogel (4.76 mg with $200 \mu \mathrm{g}$ BSA) was incubated with $50 \mathrm{nM}$ MMP-2 enzyme in $1 \mathrm{~mL}$ Tris buffer at $37^{\circ} \mathrm{C}$ and at defined intervals the enzymatic reaction was quenched with $20 \mathrm{mM}$ EDTA and the filtrates collected (using $100 \mathrm{KDa}$ Amicon filter and centrifuged at $4000 \mathrm{rpm}$ at room temperature). The released BSA was quantified using the micro-BCA assay and it was found that up to $76 \%$ of the protein was released within $48 \mathrm{~h}$. Control release experiments with no MMP-2 
enzyme added led to $26 \%$ protein released after $48 \mathrm{~h}$. A similar pattern of release was observed for the PON-1 containing nanogels. As can be seen in both release curves there exists a burst release component for both nanogels with or without the addition of MMP-2 enzyme. This burst release is a classic manifestation of protein release studies and can be attributed to initial release of surface bound proteins. ${ }^{46}$ 
A

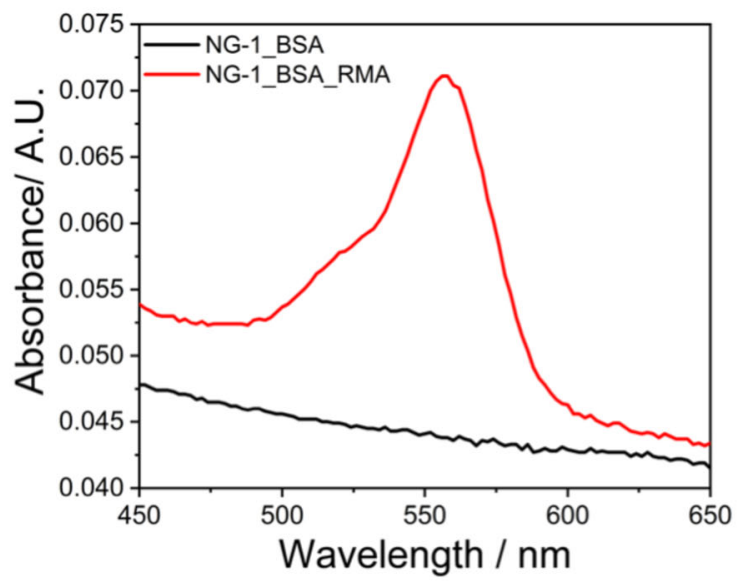

C

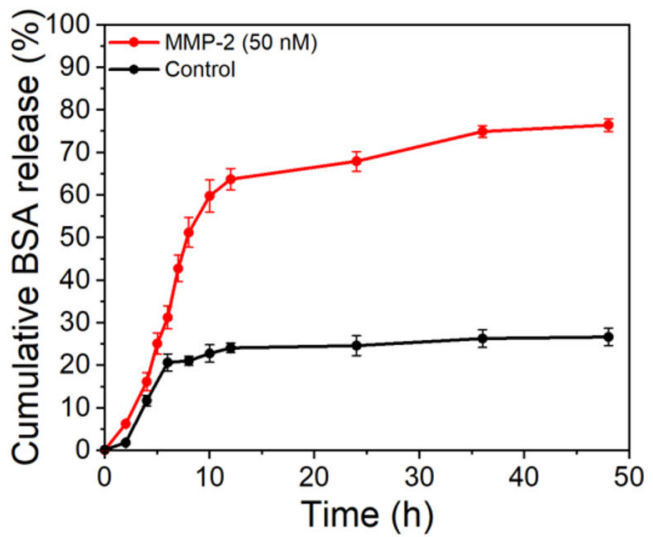

E

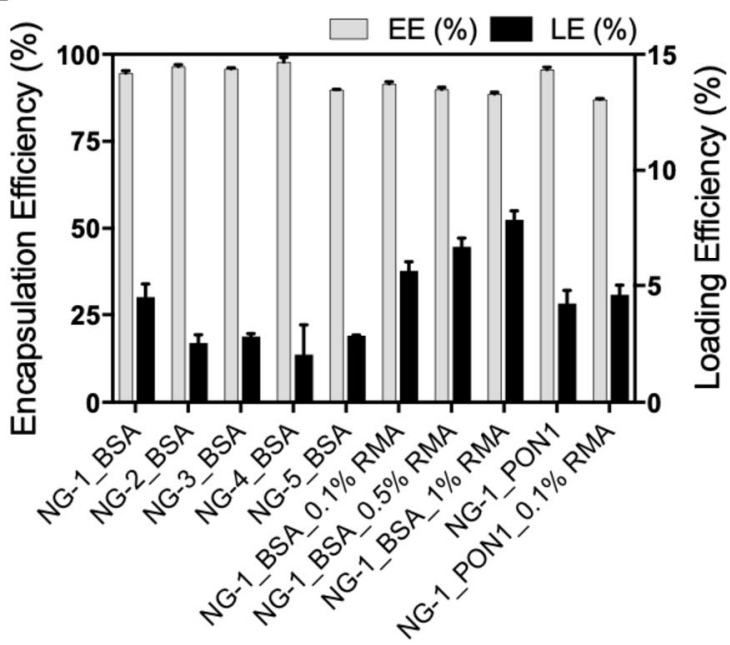

B

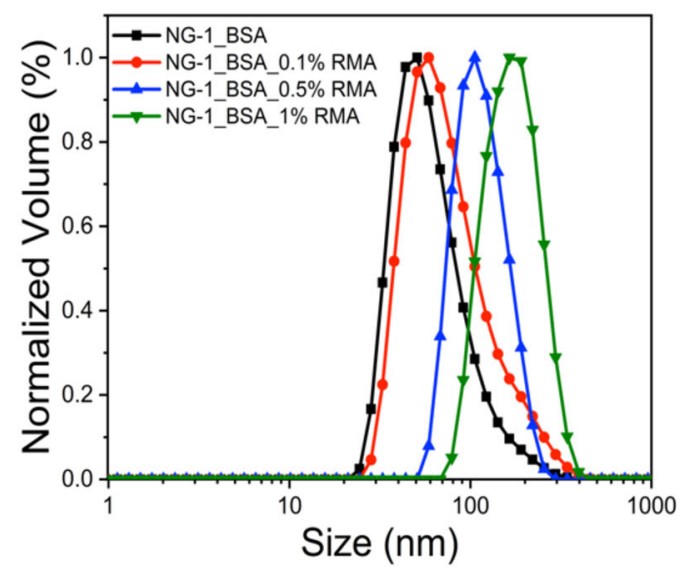

D

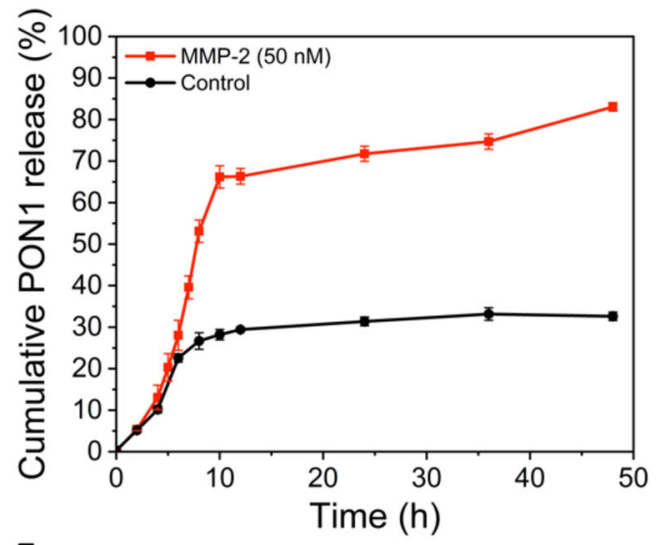

F

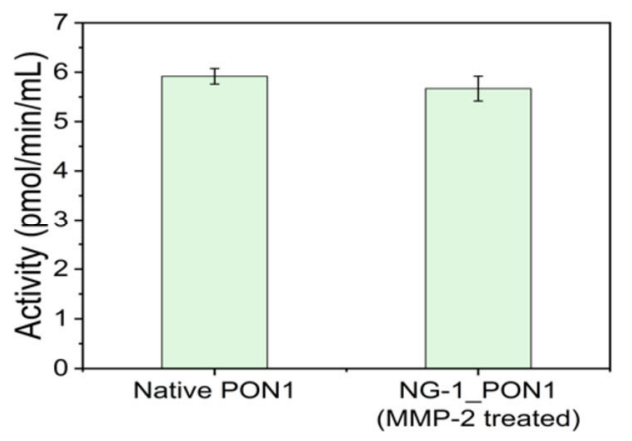

Figure 4. Characterization of fluorescent nanogels. (A) Absorbance of NG-1_BSA nanogels with and without RMA incorporation. (B) DLS measurements showing representative NG-1_BSA 
nanogels with varying molar precent of RMA fluorophore. (C) Cumulative release of BSA protein release at $37^{\circ} \mathrm{C}$ in PBS with $50 \mathrm{nM}$ MMP-2 incubation. (D) Cumulative release of PON-1 protein release at $37{ }^{\circ} \mathrm{C}$ in PBS with $50 \mathrm{nM}$ MMP-2 incubation. (E) Encapsulation efficiency and loading efficiency of BSA or PON-1 protein within NG-1 in the absence or presence of RMA. (F) Activity measurement of PON-1 enzyme post release from NG-1 nanogels after incubation with MMP-2 enzyme.

Next the percent encapsulation efficiency (\% EE) and \% loading efficiency (\% LE) of the respective proteins in the nanogels was measured whereby unencapsulated protein was measured using a micro-BCA assay following nanogel formation and purification (Figure 4E). Encapsulation efficiencies were within the range 85-97\%, with NG-1_PON1 having the highest $\%$ EE $(97 \%)$. The $\%$ LE was also calculated and found to be between 2.5 to $7.9 \%$.

Loaded PON-1 enzyme inside the nanogel sample was characterized by a PON-1 fluorometric activity assay obtained from BioVision. The PON-1 enzyme loaded nanogels (2.5 $\mu \mathrm{g}$ of NG1_PON1) were subjected to incubation at $37^{\circ} \mathrm{C}$ with $50 \mathrm{nM}$ MMP-2 enzyme, followed by catalytic activity measurement of the released PON-1. We tested the activity of native PON-1 and NG1_PON-1 at the same amount of enzyme concentration (100 ng PON-1). Similar substrate reactivity was observed with both native and MMP-2 treated and nanogel released PON-1 (Figure 4F).

Next, we sought to investigate morphological changes in the nanogel structure after proteolytic activity post incubation with MMP-2 enzyme at $37{ }^{\circ} \mathrm{C}$ incubation (Figure 5A). After incubation with MMP-2 enzyme, the hydrodymic size of the NG-1_BSA nanogels was measured at 24 and $48 \mathrm{~h}$ post incubation (Figure 5B) and we found an initial nanogel size increase from $70 \mathrm{~nm}(\mathrm{t} 0 \mathrm{~h})$ 
to $980 \mathrm{~nm}$ after $24 \mathrm{~h}$ of incubation (Figure 5B). This size increase can be attributed to cleavage of the cross-linker leading to swollen or aggregated nanogels and this change was also observed in the DLS correlation function curves (Figure 5C). The hydrodynamic size of the nanogels decreased to $13.3 \mathrm{~nm}$ after $48 \mathrm{~h}$ incubation with MMP-2 enzyme (Figure 5B). This is attributed to degradation of the nanogel particles by the enzyme. Morphological changes were also observed when the incubation products were imaged using TEM (Figure 5D).

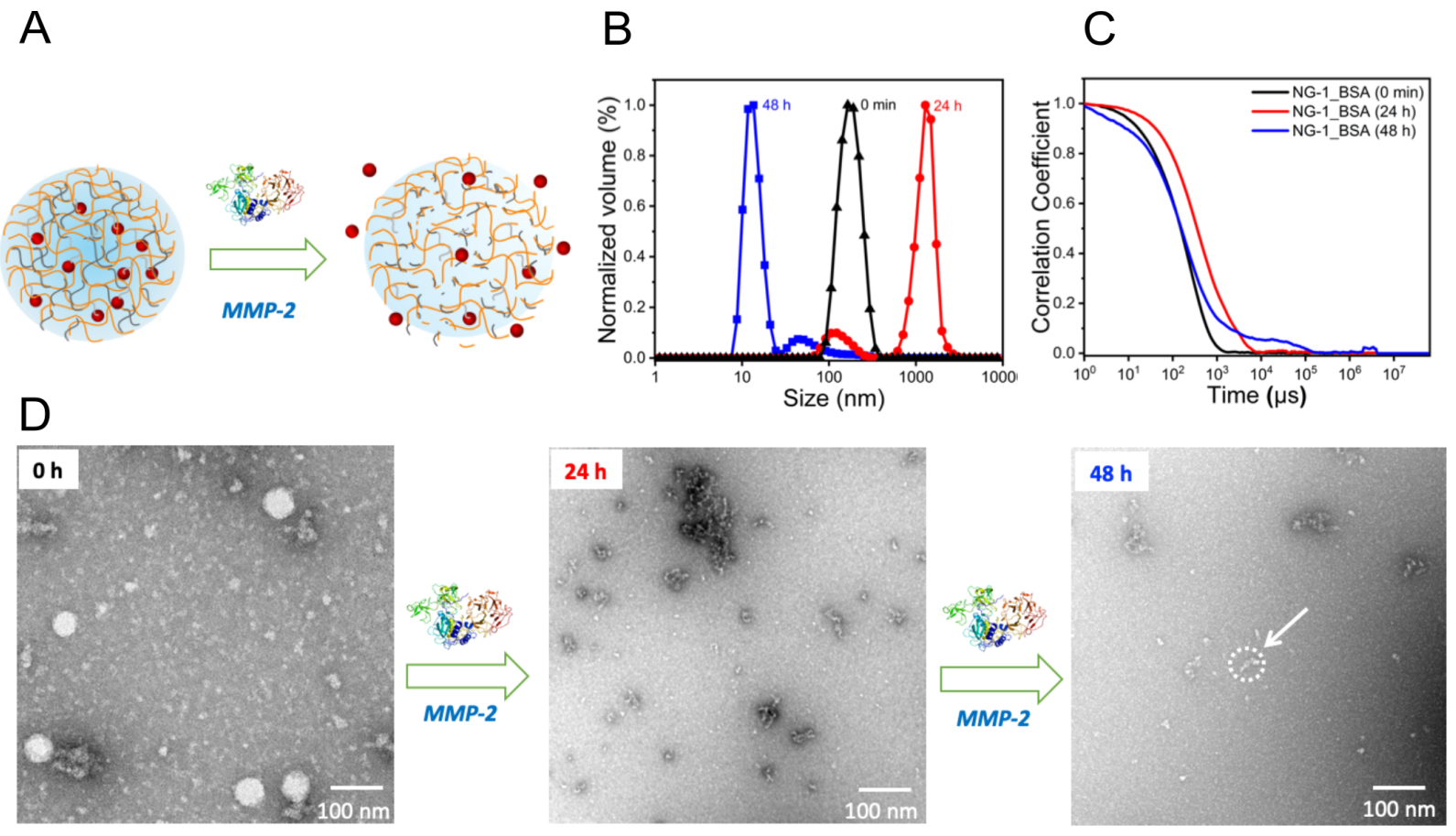

Figure 5. Investigations of MMP-2 proteolytic activity on BSA containing nanogels using DLS and TEM. (A) NG-1_BSA nanogels were prepared and incubated with MMP-2 enzyme at $\mathrm{pH} 7.5$ and $37^{\circ} \mathrm{C}$. (B) DLS of NG-1_BSA after $0 \mathrm{~h}, 24 \mathrm{~h}$ and $48 \mathrm{~h}$ incubation with MMP-2 enzyme at $\mathrm{pH}$ 7.5. (C) Correlation coefficient of the NPs (D) Negative stain TEM image after exposure with MMP-2 enzyme post $0 \mathrm{~h}, 24 \mathrm{~h}$ and $48 \mathrm{~h}$ incubation and $37^{\circ} \mathrm{C}$. 
In vitro cellular uptake and cytotoxicity in activated macrophages. We examined the cellular uptake of fluorescent nanogels with RAW 264.7 macrophage cells using confocal microscopy with the $\lambda$ ex: $553 \mathrm{~nm}$ of RMA (Figure 6A). RAW 264.7 macrophages were incubated with $100 \mu \mathrm{g} / \mathrm{mL}$ NG-1_PON1 with $0.1 \%$ RMA for $24 \mathrm{~h}$ at $37^{\circ} \mathrm{C}$. The nanogels were shown to efficiently internalize within the cells and appeared in the peri-nuclear region after $24 \mathrm{~h}$ incubation (Figure 6A), furthermore we did not observe any detrimental effects to the cells, confirming the biocompatibility of the nanogels.

A

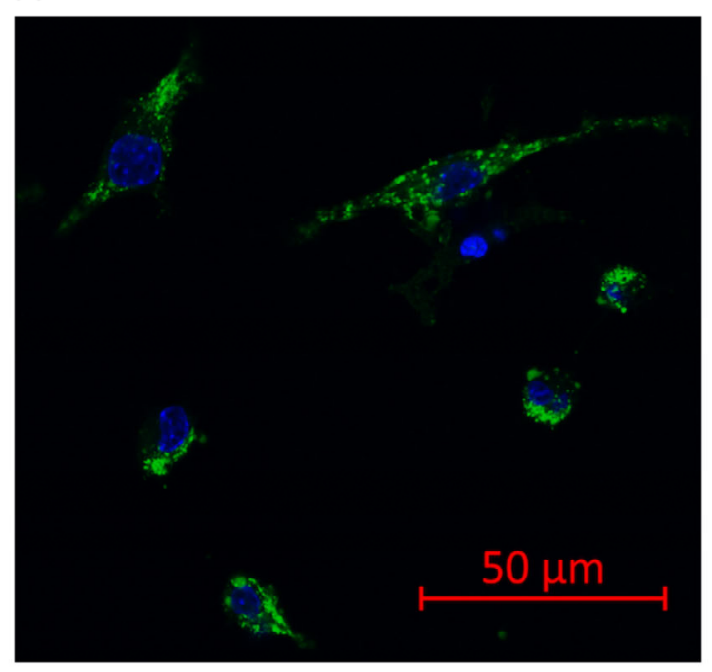

B

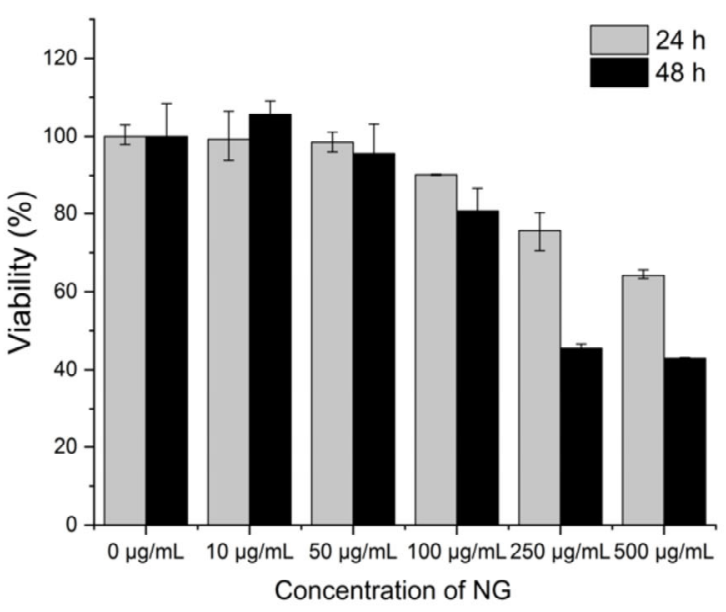

Figure 6. Cellular uptake and cell cytotoxicity measurements of NG-1_PON-1.

The biocompatibility of nanogels is an important parameter and we further investigated this using the Cell Counting Kit-8 (CCK-8) toxicity assay. The RAW 264.7 cell viability was then assessed after incubation of the nanogels at different concentrations of $0,10,50,100,250,500 \mu \mathrm{g} / \mathrm{mL}$ (Figure 6B). Cell viability after $24 \mathrm{~h}$ and $48 \mathrm{~h}$ incubation remained $>80 \%$ up to $100 \mu \mathrm{g} / \mathrm{mL}$. 
Since the retention of LDL in the artery walls leads to its oxidation and highly atherogenic particles that induce an inflammatory cascade, oxidative stress is therefore an important therapeutic parameter. OxLDL is recognized by scavenger receptors on macrophages in addition to other cells. The excessive uptake of oxLDL by macrophages leads to their conversion into foam cells. The peroxidation of LDL is driven in particular, by the reaction of hydroxyl radicals $\left({ }^{\bullet} \mathrm{OH}\right)$ with polyunsaturated fatty acid side chains of phospholipids in the lipoprotein shell. This reaction generates $\left(\mathrm{LOO}^{\bullet}\right)$ which leads to the propagation of radical reactions involving hydrogen abstraction from surrounding phospholipids, or leads to an increase in secondary peroxidation. In addition to oxidized phospholipids, reactive lipid aldehydes also lead to protein modifications and modification of LDL with malondialdehyde is the key reactant used in bioactivity assays as a test for oxLDL though the diversity of LDL oxidation products in vivo is much more complex. ${ }^{18}$ As a proof-of-concept study, we examined whether treatment with native PON-1 or PON-1 loaded NG1 nanogel is effective in inhibiting foam cell formation. RAW264.7 cells were stimulated with $(100 \mathrm{ng} / \mathrm{mL})$ LPS and $100 \mathrm{IU} / \mathrm{mL}$ IFN- $\gamma$ for $24 \mathrm{~h}$ then treated with $50 \mu \mathrm{g} / \mathrm{mL}$ ox-LDL for $24 \mathrm{~h}$. Cells were preincubated with either $10 \mu \mathrm{g} / \mathrm{mL}$ PON-1 or an equivalent dose of PON-1 in nanogels (NG-1_PON-1). The control experiment had no oxLDL added to the cells. Following incubation, the cells were washed and fixed using $10 \%$ formalin solution for 15 minutes, followed by staining with an oil red O (ORO) and hematoxylin cocktail mixture. The effect of PON-1 or NG-1_PON1 was investigated by visualizing and quantifying the oil droplet formation within the macrophages indicating the level of foam cell formation. Both native PON-1 and PON-1 loaded nanogels notably suppressed foam cell formation observed by light microscopy (Figure 7A-D) and this was further shown post quantification of ORO absorbance (Figure 7E). 

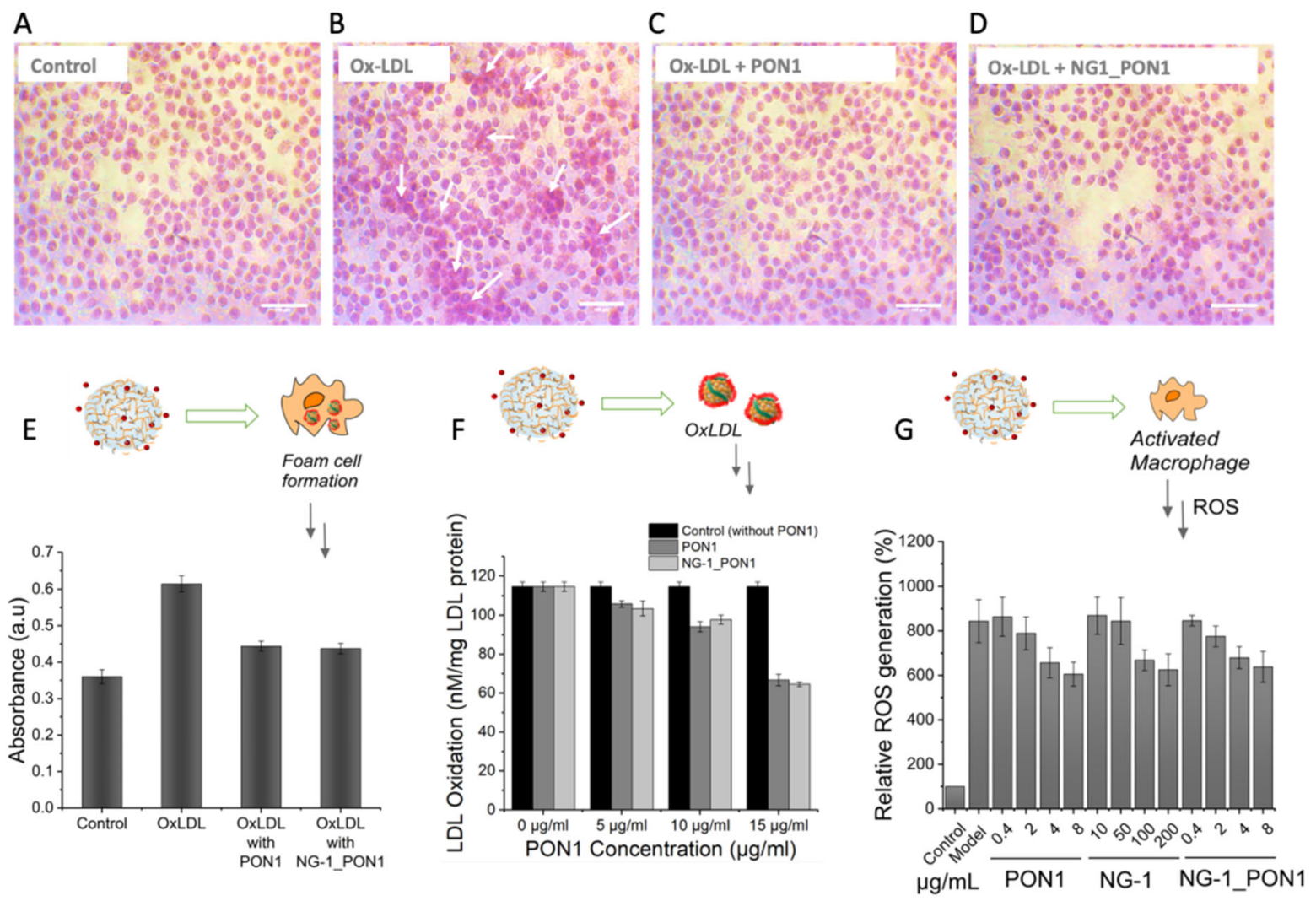

Figure 7. Antioxidizing effects of PON-1 nanogels. Oil red assay in RAW 264.7 cell lines (A) control (without Ox-LDL). (B) Ox-LDL, white arrows indicate foam cell populations. (C) OxLDL preincubated with PON1 enzyme. (D) Ox-LDL preincubated with NG-1_PON1. (E) Absorbance of oil red incubated samples at $492 \mathrm{~nm}$. (F) Cell free LDL oxidation by TBARS assay in different PON1 concentration. (G) ROS assay in THP-1 cells after exposure to PON-1, nanogels (NG-1) and NG-1_PON1 concentration.

Effects of PON-1 nanogels on oxidation of LDL. Under physiological conditions PON-1 inhibits copper induced LDL oxidation and thereby stimulates macrophage cholesterol efflux. We used, LDL $(50 \mu \mathrm{g} / \mathrm{mL})$ in PBS buffer and preincubated it with and without addition of native PON-1 and NG-1_PON1 in three different concentrations for 60 minutes at room temperature. Then, $5 \mu \mathrm{M}$ 
$\mathrm{Cu}^{2+}$ was added and incubated further for $4 \mathrm{~h}$ at $37^{\circ} \mathrm{C}$. The extent of oxidation was measured by the thiobarbituric acid reactive substrate (TBARS) assay. It was revealed that the higher dose of PON-1 or, NG-1_PON1 markedly reduced LDL oxidation induced by $5 \mu \mathrm{M} \mathrm{Cu}{ }^{2+}$. However, both native PON-1 and released PON-1 from nanogels showed similar effectiveness towards the inhibition of LDL oxidation (Figure 7F) - and this further confirms the viability of PON-1 released from the nanogels.

Reactive oxygen species (ROS) scavenging assay. Oxidative stress induced by generation of excess reactive oxygen species has emerged as a critical mechanism in atherosclerosis. Therefore, we examined whether PON-1 and PON-1 loaded nanogels could inhibit the overexpression of ROS production in activated monocytes. Monocytes are activated in an oxidant and an inflammatory atheroma environment and differentiate into macrophages. This environment promotes LDL oxidation and uptake by macrophages, which then become lipid laden foam cells. Firstly, THP-1 cells were differentiated into adherent macrophages (denoted THP-1 activated). The cells were then exposed to different concentrations of PON-1 (PON-1: 0.4; $2 ; 4$ and $8 \mu \mathrm{g} / \mathrm{mL}$ ), nanogels (NG1: $10 ; 50 ; 100$ and $200 \mu \mathrm{g} / \mathrm{mL}$ ) or nanogels containing PON-1 (PON-1/NG-1: 0.4/10; 2/50; 4/100 and $8 / 200 \mu \mathrm{g} / \mathrm{mL}$ ) for 24 hours, and ROS production was induced by exposure to $1 \mathrm{mM} \mathrm{H}_{2} \mathrm{O}_{2}$ in $200 \mu \mathrm{L}$ for 2 hours. With increasing PON-1 enzyme concentration the generated ROS production was reduced and a similar trend was observed with NG-1_PON1 nanogels, the nanogels were also able to reduce ROS production in a dose-dependent manner (Figure 7G). Interestingly, we observed a similar trend for the empty nanogels (NG-1) in this study as well and this may suggest that the nanogel composition itself is effective at quenching generated ROS. 


\section{CONCLUSION}

In this work we have developed nanogel based nanoparticles that are formed using mild reaction conditions in pure water, with the ability to encapsulate a viable payload of a potent anti-oxidizing and anti-atherogenic PON-1 enzyme. We have demonstrated the triggered release of the enzyme via MMP-2 enzymes and shown the released enzyme to be biologically active. Activated macrophages treated with PON-1 nanogels were able to reduce the formation of macrophage foam cells, reduce the direct oxidation of LDL and to temper reactive oxygen species. These proof-ofconcept studies demonstrate the potential of these novel nanotherapies for in vivo atherosclerosis therapy.

\section{ASSOCIATED CONTENT}

\section{Supporting information paragraph}

Materials and further figures can be accessed free of charge via the Internet at http://pubs.acs.org.

Figures SI 1-7 and SI Tables 1-4, ${ }^{1} \mathrm{H}$ NMR, MALDI and HPLC traces.

\section{AUTHOR INFORMATION}

Corresponding Author

Email: Nazila.kamaly@imperial.ac.uk

\section{Author Contributions}


S.B. and N.K. designed research; S.B., H.A.K., M.R., J.H.L., P.J.K., S.B-S., M.K., S.C., and N.K. performed research; S.B., T.L.A., K.A. and N.K. analyzed data; S.B. and N.K. wrote the paper.

\section{Notes}

All authors declare no conflicts.

\section{ACKNOWLEDGMENT}

This research was supported by a Lundbeck Fellowship awarded to N.K (R215-2015-4190). S.B. acknowledges support from the Technical University of Denmark, Department of Health Technology.

\section{REFERENCES}

1. Kamaly, N.; Fredman, G.; Fojas, J. J.; Subramanian, M.; Choi, W. I.; Zepeda, K.; Vilos, C.; Yu, M.; Gadde, S.; Wu, J.; Milton, J.; Carvalho Leitao, R.; Rosa Fernandes, L.; Hasan, M.; Gao, H.; Nguyen, V.; Harris, J.; Tabas, I.; Farokhzad, O. C., Targeted Interleukin-10 Nanotherapeutics Developed with a Microfluidic Chip Enhance Resolution of Inflammation in Advanced Atherosclerosis. ACS Nano 2016, 10, (5), 5280-92.

2. $\quad$ Fredman, G.; Kamaly, N.; Spolitu, S.; Milton, J.; Ghorpade, D.; Chiasson, R.; Kuriakose, G.; Perretti, M.; Farokzhad, O.; Tabas, I., Targeted nanoparticles containing the proresolving peptide Ac2-26 protect against advanced atherosclerosis in hypercholesterolemic mice. Sci Transl Med 2015, 7, (275), 275ra20.

3. Schwenke, D. C.; Carew, T. E., Initiation of atherosclerotic lesions in cholesterol-fed rabbits. II. Selective retention of LDL vs. selective increases in LDL permeability in susceptible sites of arteries. Arteriosclerosis 1989, 9, (6), 908-18.

4. Gistera, A.; Hansson, G. K., The immunology of atherosclerosis. Nat Rev Nephrol 2017, 13, (6), 368-380.

5. In Endotext, Feingold, K. R.; Anawalt, B.; Boyce, A.; Chrousos, G.; Dungan, K.; Grossman, A.; Hershman, J. M.; Kaltsas, G.; Koch, C.; Kopp, P.; Korbonits, M.; McLachlan, R.; Morley, J. E.; New, M.; Perreault, L.; Purnell, J.; Rebar, R.; Singer, F.; Trence, D. L.; Vinik, A.; Wilson, D. P., Eds. South Dartmouth (MA), 2000.

6. Yurdagul, A., Jr.; Doran, A. C.; Cai, B.; Fredman, G.; Tabas, I. A., Mechanisms and Consequences of Defective Efferocytosis in Atherosclerosis. Front Cardiovasc Med 2017, 4, 86. 7. Anselmo, A. C.; Gokarn, Y.; Mitragotri, S., Non-invasive delivery strategies for biologics. Nat Rev Drug Discov 2019, 18, (1), 19-40.

8. Zelikin, A. N.; Ehrhardt, C.; Healy, A. M., Materials and methods for delivery of biological drugs. Nat Chem 2016, 8, (11), 997-1007. 
9. Andrews, L.; Ralston, S.; Blomme, E.; Barnhart, K., A snapshot of biologic drug development: Challenges and opportunities. Hum Exp Toxicol 2015, 34, (12), 1279-85.

10. Pfister, D.; Morbidelli, M., Process for protein PEGylation. J Control Release 2014, 180, 134-49.

11. Yu, M.; Wu, J.; Shi, J.; Farokhzad, O. C., Nanotechnology for protein delivery: Overview and perspectives. $J$ Control Release 2016, 240, 24-37.

12. Liu, Y.; Du, J.; Yan, M.; Lau, M. Y.; Hu, J.; Han, H.; Yang, O. O.; Liang, S.; Wei, W.; Wang, H.; Li, J.; Zhu, X.; Shi, L.; Chen, W.; Ji, C.; Lu, Y., Biomimetic enzyme nanocomplexes and their use as antidotes and preventive measures for alcohol intoxication. Nat Nanotechnol 2013, 8, (3), 187-92.

13. Kamaly, N.; Fredman, G.; Subramanian, M.; Gadde, S.; Pesic, A.; Cheung, L.; Fayad, Z. A.; Langer, R.; Tabas, I.; Farokhzad, O. C., Development and in vivo efficacy of targeted polymeric inflammation-resolving nanoparticles. Proc Natl Acad Sci U S A 2013, 110, (16), 6506-11.

14. Guo, Z.; Van Remmen, H.; Yang, H.; Chen, X.; Mele, J.; Vijg, J.; Epstein, C. J.; Ho, Y. S.; Richardson, A., Changes in expression of antioxidant enzymes affect cell-mediated LDL oxidation and oxidized LDL-induced apoptosis in mouse aortic cells. Arterioscler Thromb Vasc Biol 2001, 21, (7), 1131-8.

15. Steinbrecher, U. P.; Pritchard, P. H., Hydrolysis of phosphatidylcholine during LDL oxidation is mediated by platelet-activating factor acetylhydrolase. J Lipid Res 1989, 30, (3), 305-15.

16. Watson, A. D.; Berliner, J. A.; Hama, S. Y.; La Du, B. N.; Faull, K. F.; Fogelman, A. M.; Navab, M., Protective effect of high density lipoprotein associated paraoxonase. Inhibition of the biological activity of minimally oxidized low density lipoprotein. J Clin Invest 1995, 96, (6), 2882-91.

17. Istvan, E. S.; Deisenhofer, J., Structural mechanism for statin inhibition of HMG-CoA reductase. Science 2001, 292, (5519), 1160-4.

18. Mark, D. B.; Richman, I.; Hlatky, M. A., Proprotein Convertase Subtilisin/Kexin Type 9 Inhibitor Therapy-Breakthrough in Low-Density Lipoprotein Cholesterol Lowering, Breakdown in Value. JAMA Cardiol 2017, 2, (10), 1066-1068.

19. Aviram, M.; Rosenblat, M.; Bisgaier, C. L.; Newton, R. S.; Primo-Parmo, S. L.; La Du, B. N., Paraoxonase inhibits high-density lipoprotein oxidation and preserves its functions. A possible peroxidative role for paraoxonase. J Clin Invest 1998, 101, (8), 1581-90.

20. Harel, M.; Aharoni, A.; Gaidukov, L.; Brumshtein, B.; Khersonsky, O.; Meged, R.; Dvir, H.; Ravelli, R. B.; McCarthy, A.; Toker, L.; Silman, I.; Sussman, J. L.; Tawfik, D. S., Structure and evolution of the serum paraoxonase family of detoxifying and anti-atherosclerotic enzymes. Nat Struct Mol Biol 2004, 11, (5), 412-9.

21. Durrington, P. N.; Mackness, B.; Mackness, M. I., Paraoxonase and atherosclerosis. Arterioscler Thromb Vasc Biol 2001, 21, (4), 473-80.

22. Shih, D. M.; Gu, L.; Xia, Y. R.; Navab, M.; Li, W. F.; Hama, S.; Castellani, L. W.; Furlong, C. E.; Costa, L. G.; Fogelman, A. M.; Lusis, A. J., Mice lacking serum paraoxonase are susceptible to organophosphate toxicity and atherosclerosis. Nature 1998, 394, (6690), 284-7.

23. Tward, A.; Xia, Y. R.; Wang, X. P.; Shi, Y. S.; Park, C.; Castellani, L. W.; Lusis, A. J.; Shih, D. M., Decreased atherosclerotic lesion formation in human serum paraoxonase transgenic mice. Circulation 2002, 106, (4), 484-90. 
24. Zhang, H.; Zhai, Y.; Wang, J.; Zhai, G., New progress and prospects: The application of nanogel in drug delivery. Mater Sci Eng C Mater Biol Appl 2016, 60, 560-568.

25. Wen, Y.; Oh, J. K., Recent strategies to develop polysaccharide-based nanomaterials for biomedical applications. Macromol Rapid Commun 2014, 35, (21), 1819-32.

26. Kabanov, A. V.; Vinogradov, S. V., Nanogels as pharmaceutical carriers: finite networks of infinite capabilities. Angew Chem Int Ed Engl 2009, 48, (30), 5418-29.

27. Chacko, R. T.; Ventura, J.; Zhuang, J. M.; Thayumanavan, S., Polymer nanogels: A versatile nanoscopic drug delivery platform. Adv Drug Deliver Rev 2012, 64, (9), 836-851. 28. Giulbudagian, M.; Yealland, G.; Honzke, S.; Edlich, A.; Geisendorfer, B.; Kleuser, B.; Hedtrich, S.; Calderon, M., Breaking the Barrier - Potent Anti-Inflammatory Activity following Efficient Topical Delivery of Etanercept using Thermoresponsive Nanogels. Theranostics 2018, $8,(2), 450-463$.

29. Azegami, T.; Yuki, Y.; Nakahashi, R.; Itoh, H.; Kiyono, H., Nanogel-based nasal vaccines for infectious and lifestyle-related diseases. Mol Immunol 2017. 98, 19-24.

30. Zhang, X.; Malhotra, S.; Molina, M.; Haag, R., Micro- and nanogels with labile crosslinks - from synthesis to biomedical applications. Chem Soc Rev 2015, 44, (7), 1948-73.

31. Soni, K. S.; Desale, S. S.; Bronich, T. K., Nanogels: An overview of properties, biomedical applications and obstacles to clinical translation. J Control Release 2016, 240, 109126.

32. Motornov, M.; Roiter, Y.; Tokarev, I.; Minko, S., Stimuli-responsive nanoparticles, nanogels and capsules for integrated multifunctional intelligent systems. Prog Polym Sci 2010, $35,(1-2), 174-211$.

33. Zha, L. S.; Banik, B.; Alexis, F., Stimulus responsive nanogels for drug delivery. Soft Matter 2011, 7, (13), 5908-5916.

34. Vacek, T. P.; Rehman, S.; Neamtu, D.; Yu, S.; Givimani, S.; Tyagi, S. C., Matrix metalloproteinases in atherosclerosis: role of nitric oxide, hydrogen sulfide, homocysteine, and polymorphisms. Vasc Health Risk Manag 2015, 11, 173-83.

35. Johnson, J. L., Metalloproteinases in atherosclerosis. Eur J Pharmacol 2017, 816, 93106.

36. Bhuchar, N.; Sunasee, R.; Ishihara, K.; Thundat, T.; Narain, R., Degradable thermoresponsive nanogels for protein encapsulation and controlled release. Bioconjug Chem 2012, 23, (1), 75-83.

37. Slaughter, B. V.; Khurshid, S. S.; Fisher, O. Z.; Khademhosseini, A.; Peppas, N. A., Hydrogels in regenerative medicine. Adv Mater 2009, 21, (32-33), 3307-29.

38. Smith, P. K.; Krohn, R. I.; Hermanson, G.; Mallia, A.; Gartner, F.; Provenzano, M.; Fujimoto, E.; Goeke, N.; Olson, B.; Klenk, D., Measurement of protein using bicinchoninic acid. Analytical biochemistry 1985, 150, (1), 76-85.

39. Hu, Q.; Katti, P. S.; Gu, Z., Enzyme-responsive nanomaterials for controlled drug delivery. Nanoscale 2014, 6, (21), 12273-86.

40. de la Rica, R.; Aili, D.; Stevens, M. M., Enzyme-responsive nanoparticles for drug release and diagnostics. Adv Drug Deliv Rev 2012, 64, (11), 967-78.

41. Yao, Q.; Kou, L.; Tu, Y.; Zhu, L., MMP-Responsive 'Smart' Drug Delivery and Tumor Targeting. Trends Pharmacol Sci 2018, 39, (8), 766-781.

42. van Duijnhoven, S. M.; Robillard, M. S.; Nicolay, K.; Grull, H., Tumor targeting of MMP-2/9 activatable cell-penetrating imaging probes is caused by tumor-independent activation. J Nucl Med 2011, 52, (2), 279-86. 
43. Aguilera, T. A.; Olson, E. S.; Timmers, M. M.; Jiang, T.; Tsien, R. Y., Systemic in vivo distribution of activatable cell penetrating peptides is superior to that of cell penetrating peptides. Integr Biol (Camb) 2009, 1, (5-6), 371-81.

44. Povoski, S. P.; Davis, P. D.; Colcher, D.; Martin, E. W., Jr., Single molecular weight discrete PEG compounds: emerging roles in molecular diagnostics, imaging and therapeutics. Expert Rev Mol Diagn 2013, 13, (4), 315-9.

45. Yan, M.; Du, J.; Gu, Z.; Liang, M.; Hu, Y.; Zhang, W.; Priceman, S.; Wu, L.; Zhou, Z. H.; Liu, Z.; Segura, T.; Tang, Y.; Lu, Y., A novel intracellular protein delivery platform based on single-protein nanocapsules. Nat Nanotechnol 2010, 5, (1), 48-53.

46. Kamaly, N.; Yameen, B.; Wu, J.; Farokhzad, O. C., Degradable Controlled-Release Polymers and Polymeric Nanoparticles: Mechanisms of Controlling Drug Release. Chem Rev 2016, 116, (4), 2602-63.

\section{Table of Contents Graphic}

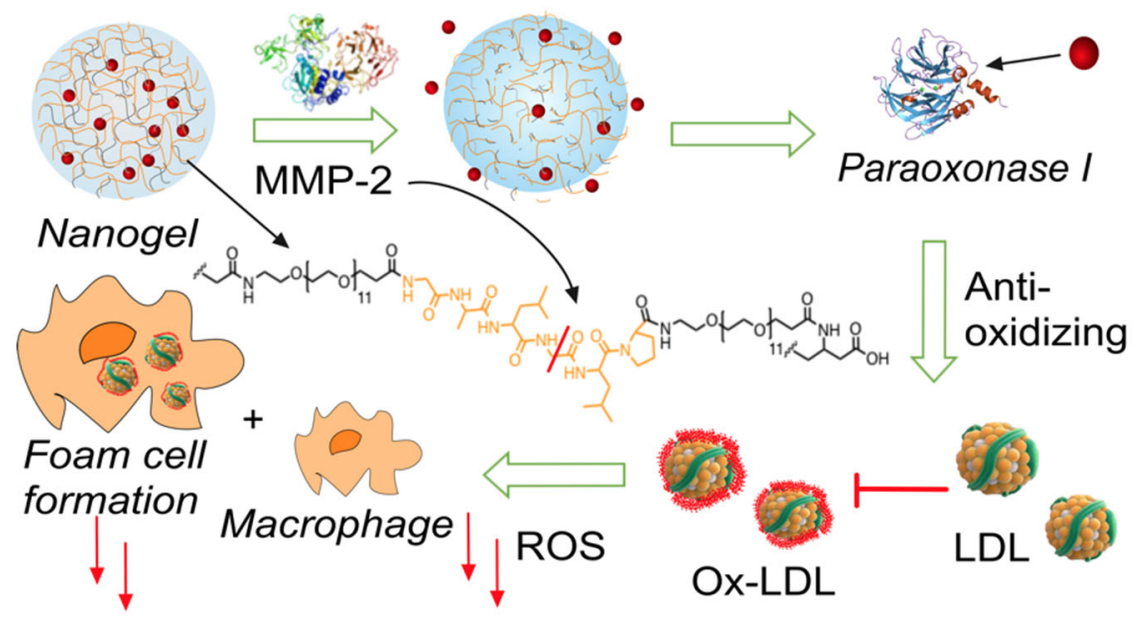

